\title{
Articles
}

\section{FAIRNESS, EFFICIENCY, AND INSIDER TRADING: DECONSTRUCTING THE COIN OF THE REALM IN THE INFORMATION AGE}

\author{
Kimberly D. Krawiec
}

Our era aptly has been styled, and well may be remembered as, the "age of information." Francis Bacon recognized nearly 400 years ago that "knowledge is power," but only in the last generation has it risen to the equivalent of the coin of the realm. Nowhere is this commodity more valuable or volatile than in the world of high finance, where facts worth fortunes while secret may be rendered worthless once revealed. ${ }^{2}$

\section{INTRODUCTION}

Whether and how the federal securities laws should prohibit insider trading ${ }^{3}$ is one of the most hotly debated topics in the securities law literature. Paradoxically, both the theoretical analysis and the legal rules concerning insider trading remain extraordinarily vague and ill-formed. For example, commentators are unable to agree whether insider trading causes losses to other marketplace actors and, if so, to whom; ${ }^{4}$ whether insider

1 Visiting Professor, UCLA School of Law; Associate Professor, University of Oregon Sehool of Law. Although this paper has benefited from the comments of many readers, I am particularly indebted to Professor Keith Aoki for his helpful insights on the unique complexities of information. Portions of this Article were presented at the First Annual Covell Conference on Corporate Govemance at UCLA School of Law and the Sixteenth Annual Sokol Colloquium on Private International Lave at the University of Virginia School of Law, and I am grateful to the participants at those events for their comments and questions. Finally, I am grateful to Professors Stephen M. Bainbridge, G. Mîtu Gulati, Peter H. Huang, Thomas Wuil Joo, William A. Klein, Richard W. Painter, and James B. Speta and to Dean David Van Zandt for helpful comments and suggestions on earlier dralts of this Article.

2 SEC v. Materia, 745 F.2d 197, 198 (2d Cir. 1984).

3 I use the phrase "insider trading" to refer to all trading (whether in stocks or other commodities) while in possession of material nonpublic information, regardless of whether the trader is an actual corporate insider and regardless of whether the conduct is illegal. This definition is analogous to the cionomic, as opposed to the legal, definition of insider trading, which considers insider trading to involve "trading by parties who are better informed than their trading partners." Dennis W. Carlton \& Danisl R. Fischel, The Regulation of Insider Trading, 35 STAN. L. REV. 857, 860 (1983). The cconomic definition of insider trading, in other words, "includes all trades where information is asymmetric." $/ d$.

4 See, e.g., Leo Katz, Ill Gotten Gains: Evasion, Blackimall, Fraud and kindied puzzles OF THE LAW 172 (1996) (arguing that it is not the actual purchasers or sellers of sceurities who are in- 
trading should be prohibited and, if so, how ${ }^{5}$ or whether such trading causes greater or less market efficiency. ${ }^{6}$ Similarly, neither the courts, the legislature, nor the Securities and Exchange Commission ("Commission") has clearly or convincingly articulated what social policy the insider trading prohibition is meant to further, how the prohibition in fact furthers that policy, or why the prohibition covers some types of insider trading but not others. ${ }^{7}$

Why is there such a lack of clarity and consensus regarding an activity typically vilified in the public mind as one of the ultimate manifestations of greed and dishonesty? ${ }^{8}$ One might assume that such an intensity of public

jured by insider trading, but those who would have purchased or sold securities if the insider had not done so); Stephen Bainbridge, The Insider Trading Prohibition: A Legal and Economic Enigma, $38 \mathrm{U}$. FLA. L. REV. 35, 50-62 (1986) (arguing that insider trading may injure the issuing firm and its sharcholders, but questioning whether contemporaneous marketplace traders are injured); Nicholas L. Georgakopoulos, Insider Trading as a Transactional Cost: A Market Microstructure Justification and Optimization of Insider Trading Regulation, 26 CONN. L. REV. 1 (1993) (arguing that insider trading increases bid-ask spreads for securities, resulting in less market liquidity).

5 See, e.g., Allison Grey Anderson, Fraud, Fiduciaries and Insider Trading, 10 HOFSTRA L. REV. 341, 375 (1982) (arguing that the insider trading prohibition should be limited to corporate insiders and market professionals); Stephen M. Bainbridge, Insider Trading Regulation: The Path Dependent Choicc Between Property Rights and Securities Fraud, 52 SMU L. Rev. 1589 (1999) (advocating a property rights-based approach to insider trading regulation); Victor Brudney, Insiders, Outsiders, and Informational Advantages Under the Federal Securities Laws, 93 HARV. L. REv. 322 (1979) (arguing that federal securities laws should prohibit trading on informational advantages that cannot be lawfully eroded); Donna M. Nagy, Reframing the Misappropriation Theory of Insider Trading Liability: A Post-O'Hagan Suggestion, 59 OHIO ST. L.J. 1223 (1998) (arguing that the Supreme Court has adopted an unnecessarily restrictive view of illegal insider trading and advocating a broader "fraud on investors" theory of insider trading liability); Larry E. Ribstein, Federalism and Insider Trading, 6 SUP. CT. ECON. REV. 123, 12425 (1998) (arguing that insider trading should be governed by state laws that protect property rights in valuable information).

${ }^{6}$ See, e.g., Ronald J. Gilson \& Reinier H. Kraakman, The Mechanisms of Markel Efficiency, 70 VA. L. REV. 549, 630-32 (1984) (arguing that insider trading transmits information to the marketplace in an inefficient manner and is thus unlikely to increase informational efficiency substantially unless insiders are required to disclose their trades); Edmund W. Kitch, The Law and Economics of Rights in Valuable Information, 9 J. LEGAL STUD. 683, 719 (1980) (arguing that the Securities and Exchange Commission's bar against insider trading has made the stock market less efficient); Henry G. Manne, Insider Trading and the Law Professors, 23 VAND. L. REV. 547, 565-76 (1970) (arguing that insider trading leads to more accurate stock prices by conveying information to the marketplace).

7 See, e.g., Saikrishna Prakash, Our Dysfunctional Insider Trading Regime, 99 Colum. L. REv. 1491,1493 (1999) (referring to the U.S. insider trading regime as "astonishingly dysfunctional"); Bainbridge, supra note 4, at 68 ("Despite a lengthy and active debate, the insider trading prohibition remains both a legal and economic enigma."); James Boyle, A Theory of Law and Information: Copyright. Spleens, Blackmail, and Insider Trading, 80 CAL. L. REv. 1413, 1429 (1992) ("All scholars scem to agree that, despite widespread popular support for sanctions against insider trading, the reasons for such sanctions are hard to identify."); James D. Cox, Insider Trading and Contracting: A Critical Response to the "Chicago School," 1986 DUKE L.J. 628, 634 ("The fact that such an aggressive level of regulation exists without a coherent, let alone articulated, philosophy of regulation is one of the most unsettling aspects of the federal securities laws."); Jill E. Fisch, Start Making Sense: An Analysis and Proposal for Insider Trading Regulation, 26 GA. L. REV. 179, 179 (1991) ("When Charles Dickens wrote "the law is a[n] ass,' he might well have been describing the law governing insider trading.").

8 See Stephen M. Bainbridge, Insider Trading 4 (1999) (stating that "insider trading . . . remains one of the most controversial aspects of securities law"); Cox, supra note 7, at 628 ("American 
feeling and scholarly debate would create a cogent and comprehensive analysis of the issue. In fact, just the opposite is true.

Scholars have long struggled with the insider trading puzzle and have sought the resolution of that puzzle in such diverse fields as economics, ${ }^{9}$ morality, ${ }^{10}$ feminist legal theory, ${ }^{11}$ and sociology. ${ }^{12}$ While contributing enormously to the insider trading debate, such approaches have been unable to resolve the insider trading paradox.

What is the special character of insider trading that leads to this apparently unresolvable puzzle? In this Article, I argue that there is, in fact, nothing special about insider trading that creates this dilemma, but rather there is something special about the nature of information itself. Accordingly, this theoretical dilemma is not limited to insider trading regulation, but rather pervades all areas of intellectual property law. ${ }^{13}$ By analyzing in-

jurisprudence abhors insider trading with a fervor reserved for those who scoff at motherhood, apple pie, and baseball. The commonly stated reasons for this reaction to insider trading are many and unparsua. sive. The case law barely suggests why insider trading is harmful."); Gary Lawson. The Ethies of Insider Trading, 11 HARV. J.L. \& PUB. POL'Y 727, 727 (1988) ("Legal and moral condemnation is heaped upon insider trading with uncommon hostility....").

9 See, e.g., HeNRY G. MANNE, INSider TRADING AND the Stock MARKet (1966) [hercinafter, MANNE, INSIDER TRADING]; David D. Haddock \& Jonathan R. Macey, A Coasian Model of Insider Trading, 80 Nw. U. L. REv. 1449, 1457-58 (1987) [hereinafter Haddoek \& Maccy, Coasian Model;; David D. Haddock \& Jonathan R. Macey, Regulation on Dentand: A Privafe Interest Model, with on Application to Insider Trading, 30 J.L. \& EcoN. 311 (1987) [hercinafter Haddosk \& Maccy, Regulation on Demand]; Jonathan R. Macey, From Fairness to Contract: The New Dircction of the Rules Against Insider Trading, 13 HOFSTRA L. REV. 9 (1984) [hereinafter Macey, From Fairness to Contrack]; Henry G. Manne, In Defense of Insider Trading, 44 HARv. BUS. REV. Nov.-Dec. 1966, at 113; Manne, supra note 6.

10 KATZ, supra note 4, at 180-89 (arguing that insider trading should be prohibited becouse it is morally wrong); KIM LANE SCHEPPELE, LEGAL SECRETS: EQUALITY AND EFFICIENCY IN THE COAMO: LAW ix (1988) [hereinafter SCHEPPELE, LEGAL SECRETS] (describing her book on the legal regulation of secrets, including the law governing insider trading, as a book about "moral philosophy"); Lawson, supra note 8 (discussing moral philosophy in the insider trading context); Kim Lane Scheppele, "It's Just Not Right": The Ethics of Insider Trading, 56 LAW \& CONTEMP. ProBS. 125 (1993) [hereinafter Seheppele, Insider Trading] (advocating an equality of access approach to insider troding regulation based on a theory of "contractarian ethics"); Alan Strudler, Moral Complaxity in the Law of Nondisclosure, 45 UCLA L. REv. 337 (1997) (defending a deontologieal treatment of the duty of disclosure required in contract negotiations); Alan Strudler \& Eric W. Orts, Moral Principle in the Law of Insider Trading, 78 TEX. L. REV. 375 (1999) (arguing that "there are good moral reasons, even in the absence of a fiduciary relationship, to recognize a duty to disclose in certain circumstances when people with material nonpublic information trade with those who lack such information").

"Judith G. Greenberg, Insider Trading and Family Values, 4 WM. \& MARY J. WOMEx \& L. 303. 307-08 (1998) (arguing that insider trading regulation has been influenced by unconseious judicial perceptions of gender roles and the dichotomous spheres of market and family).

12 SCHEPPELE, LEGAL SECRETS, supra note 10, at ix (describing her book on the legal regulation of secrets, including the law goveming insider trading, as a book about "the sociology of knowledge").

13 See Boyle, supra note 7, at 1417 ("[T]he area of legal doctrine that acknowledges that its main concem is information-conventionally defined intellectual property-is marked by severe disagreements over the most fundamental propositions."). Professor Boyle, for example, illustrates that the conceptual dilemma and legal puzzles raised by the dual nature of information in the marketplace confound the fields of copyright, blackmail, insider trading, and the treatment of genetic information. Id.; sce also 
sider trading in isolation solely as a securities regulation issue rather than as an intellectual property issue, we thus ignore not only relevant case law and legislative precedent on the subject of information regulation, but also the substantial body of scholarly work on the topic.

It is particularly striking that this segregation of insider trading from intellectual property law as a whole takes place during a period of particularly fierce debate in the courts, Congress, law reviews, and the popular and industry press over the proper scope and purpose of intellectual property law in the face of technological innovations that have opened the door to free and widespread communication and information gathering in ways previously impossible. ${ }^{14}$ Our entry into the "information age" has led many commentators to argue that copyright and, perhaps, other forms of intellectual property protection are outdated and unnecessary impediments to creation and communication in today's digital environment. ${ }^{15}$ On the other hand, technological innovation has increased the ease and accuracy with which original works can be copied and disseminated quickly and cheaply, leading other commentators to argue that we are facing an impending crisis that requires a drastic reorganization and fortification of current intellectual property laws. ${ }^{16}$ As stated by one commentator: "digital technology threat-

Stephen Breyer, The Uneasy Case for Copyright: A Study of Copyright in Books, Photocopies, and Computer Programs, 84 HARV. L. REV. 281, 282 (1970) (noting "the conflict between the need for book revenues high enough to secure adequate production and book prices low enough not to interfere with widespread dissemination of what is written"); Frank H. Easterbrook, Insider Trading, Secret Agents, Evidentiary Privileges, and the Production of Information, 1981 SUP. CT. REV. 309, 364 ("The tension between optimal use of existing information and optimal incentives to create new information pervades legal and economic problems arising out of claims to property rights in information."); Paul G. Mahoney, The Exchange As Regulator, 83 VA. L. REv. 1453, 1483-88 (1997) (discussing this tension in the context of prices generated by stock exchanges).

14 See generally Keith Aoki, (Intellectual) Property and Sovereignty: Notes Toward a Cullural Geography of Authorship, 48 STAN. L. REV. 1293, 1352 (1996) (describing this battle); Neil Weinstock Netanel, Copyright and a Democratic Civic Society, 106 YALE L.J. 283, 285-86 (1996) (same).

15 One of the most vocal proponents of this view is John Perry Barlow, Electronic Fronticr Foundation Board Member, Vice-Chair and Co-founder:

Governments of the Industrial World, you weary giants of flesh and steel, I come from Cyberspace, the new home of Mind. On behalf of the future, I ask you of the past to leave us alone. You are not welcome among us. You have no sovereignty where we gather. ... Your legal concepts of property, expression, identity, movement, and context do not apply to us. . . . Your increasingly obsolete information industries would perpetuate themselves by proposing laws, in Amcrica and elsewhere, that claim to own speech itself throughout the world. These laws would declare idcas to be another industrial product, no more noble than pig iron. In our world, whatever the human mind may create can be reproduced and distributed infinitely at no cost. The global conveyance of thought no longer requires your factories to accomplish.

John Perry Barlow, A Declaration of the Independence of Cyberspace (Feb. 9 1996), at http://www.cff. org/pub/Publications/John_Perry_Barlow/barlow_0296.declaration); see also David Lange, At Play in the Fields of the World: Copyright and the Construction of Authorship in the Post-Literate Millennium, 58 LAW \& CONTEMP. PROBS. 139, 144-51 (1992) (arguing that copyright and other forms of intellectual property have no place in the digital environment).

16 See generally Aoki, supra note 14, at 1352-55 (discussing what he views as a "hardening" of intellectual property rights in the digital age); Robert M. Kunstat et al., 18 NAT. L.J., May 20, 1996, at C2 
ens to upend copyright's already uneasy accommodation of public access with private ownership."

Although intellectual property law has always contained valuable, though often ignored, lessons for insider trading regulation, this current discourse is especially relevant to the insider trading debate. New information technology is particularly threatening to the legal status quo because it renders information-an already fleeting and evanescent good-even more ephemeral. Today more than ever, creative works that may have taken a lifetime to produce can be cheaply and accurately copied and disseminated to millions in mere seconds through a few keystrokes. ${ }^{18}$ This has always been the case with valuable inside information, which is easily transmitted from source to trader or tippee, then on to subsequent traders or tippees with little expense or effort.

Part II of this Article seeks an explanation for the insider trading puzzle and attributes the confusion and lack of clarity in this area of the law to an essential tension, or aporia. ${ }^{20}$ Information is both a public good and a collective good-two characteristics that, in the case of information, lead to divergent and inconsistent policy implications. ${ }^{21}$ Specifically, as a public

(advocating patent protection for sports moves, such as the slam dunk and Fosbury Flop); Netanel, supra note 14, at 286-87 (discussing the movement toward greater intellectual property protections).

17 Netanel, supra note 14, at 285.

18 Prior to the invention of modern copying techniques, such as the printing press, the copying of original works was a laborious-and highly valued-effort. In faet, seribes vere considered on a par with authors in terms of the craftsmen necessary to produce a book and skillful seribe work was often more valued than new expressions. See Keith Aoki, Authors, Inventors and Trademark Orners: Private Intellectual Property and the Public Domain, 18 COLUM.-VLA J.L. \& ARTS I, 27 (1994).

19 New information technology has, of course, increased the ease of transmission and use of inside information as well. See, e.g., Frances A. McMorris, Randall Smith \& Michael Sehroeder, Insider Case Involves a Temp at Two Brokers and Web Ring, WALL ST. J., Mar. 15, 2000, at $\mathrm{Cl}$ (discussing the prosecution of John J. Freeman, a computer graphics worker and word processor who tipped information about 23 pending mergers to friends he had met in internet chat rooms).

20 The term aporia, as applied to information economics, was borrowed from Boyle, supra nose 7, at 1420 n.5. However, the term is not only common, but some would also argue essential, to dsconstrictionist, or post-modem, philosophy and literature. Sce, eg. RICIARD BEARDSwORTt, DERRDA \& THE POLITICAL 31 (1990) (stating that the term aporia "organizes in concentrated form the overall cancems of deconstruction"); Greig E. Henderson \& Christopher Brown, Glossay of the Litcrany Thcony, at http:/utll.library.utoronto.ca/wrww/utel/glossary/Aporiahtml (defining aporia as "[a] tem used by daconstructionists to describe the point of impasse or undecidability to which reading a text necessarily gives rise").

"Aporia" is derived from the Greek aporos, which literally means "without passage." BEARDSwORTH, supra, at 33. The pre-Socratic sophists employed the term to deseribe two contradictory aphorisms of equal value. Id. Jacques Derrida, who is typically credited with bringing the term into modern usage, employed "aporia" in a different sense. For Derrida, aporia referred to an internal inconsistency or irreducibility, not to the extemal inconsistency of two separate entities. Id. at 32-33. See generally JACQUes DERRIDA, ApORIas (Thomas Dutoit trans., Stanford Univ. Press ed. 1993). It is with Derrida's intended meaning of intemal inconsistency or tension that I use the term "aporia" in this Article.

21 See infra subpart II.A (defining and contrasting the terms "public good" and "collective good"). 
good, information is often misperceived as infinite or limitless, which has led some commentators to advocate "informational-egalitarian" theories of resource sharing not seen when some commodity other than information is at issue. ${ }^{22}$ This perception is in direct contrast to information's role as a collective good, where "informational-propertarianism" reigns supreme and information is treated as a scarce and valuable commodity whose production must be encouraged through grants of private property rights in information producers. This, I argue, is the source of the familiar fairness versus efficiency debate in insider trading commentary. ${ }^{23}$

As discussed in Part III, however, deeper reflection reveals that the fairness/efficiency debate in insider trading is merely a reprise of the public/private debate that characterizes many other areas of mainstream political and legal discourse. Much contemporary legal thought, however, is critical of this attempt to distinguish public from private life, arguing that these divisions are social constructs that mask substantive decisions to tolerate inequalities in the allocation of wealth, power, justice, and information. The place of information along this public/private continuum is especially problematic because, unlike most other valuable objects, information lies particularly close to the imaginary public/private dividing line, resulting in a confusing and inconsistent legal regime.

Parts IV through VI situate insider trading regulation within the larger body of intellectual property law by discussing three potential allocations of the property right in valuable inside information. First, as discussed in Part IV, inside information could be treated as a "public resource," meaning that a person in possession of inside information could not legally exploit that advantage for personal profit. Such a regime would forbid some or all insider trading by forcing the disclosure to the marketplace of inside information prior to trading. Part IV then analyzes the most common justification for such a regulatory model: that a rule limiting insider trading promotes fairness, by preventing harm to specific traders or potential traders, or by increasing investor confidence in the securities markets. After analyzing the impacts of insider trading on stock markets and investors, Part IV concludes that, although there are some costs associated with insider trading, there are some benefits as well. Accordingly, regulators should be forced to defend limitations on insider trading by balancing the benefits of such regulation against both the costs of enforcement and the costs imposed on a marketplace in which no insider trading is permitted, rather than through a reliance on amorphous notions of fairness or investor harm.

\footnotetext{
22 The phrases "informational-egalitarian" and "informational-propertarian" are borrowed from Aoki, supra note 18 , at 10.

23 See, e.g., Saul Levmore, Securities and Secrets: Insider Trading and the Law of Contracts, 68 VA. L. REV. 117, 118 (1982) (explaining that the two primary approaches to securities regulation are "disclose or abstain," which would prohibit insider trading because it is unfair, and the "free market," which would permit insider trading because it fosters market efficiency).
} 
Alternatively, as discussed in Part V, the property right in valuable inside information could belong to issuers, as the producers of such information. The recognition that many of the fundamental issues in securities regulation essentially reduce to a matter of allocating property rights in valuable information is one of the greatest contributions of law and economics scholars to the securities law literature in recent years. This recognition, however, does not necessarily imply that information producers are entitled to private property rights in the information they create. As noted nearly two hundred years ago by William Blackstone, the source and foundation of property rights are extraordinarily important, but frequently unconsidered, elements of Western jurisprudence. ${ }^{24}$

In Part V, I argue that reliance on neoclassical economic models and Lockean natural rights-based theories have tended to induce in the insider trading context a greater than necessary commodification of information and a disregard for the inherent complexity and trade-offs involved in the propertization of information. Property rights are creations of the state designed to further a specific economic purpose. As will be seen, in the context of intellectual property law, including the law governing insider trading, that economic purpose is to strike a delicate balance between private incentives to information production and distribution on the one hand, and, on the other hand, public access to such information once produced. Granting intellectual property rights to issuers does little or nothing to incentivize information production and dissemination and fails to properly consider the public's need to access valuable nonpublic information.

Finally, as discussed in Part VI, the "property right" in valuable information could reside with outsider traders. ${ }^{25}$ This proposal stems from the recognition that, although there is no need to encourage issuers to create valuable inside information, the need to encourage the dissemination of such information to the marketplace has been recognized for many years. Accordingly, Part VI proposes a system of federal securities regulation that would permit trading by corporate outsiders, defined as those persons who are neither employees nor constructive insiders of the issuer and who did not receive their information in a tip from the issuer's employees or con-

\footnotetext{
${ }^{24}$ As stated by Blackstone:

There is nothing which so generally strikes the imagination, and engages the aftections of mankind, as the right of property.... And yet there are very few, that will give themselves the trouble to consider the original and foundation of this right. Pleased as we are with the possession, we seem afraid to look back to the means by which it was acquired, as if fearful of some defect in our title; or at best we rest satisfied with the decision of the laws in our favor, without examining the reason or authority upon which those laws have been built.

2 WilLIAM BLACKSTONE, COMMENTARIES 2 (1809).

25 Part VI employs the term "property" in an unconventional sense, albeit one that is common among insider trading scholars. See infra note 101 (discussing both the standard definition of "property" and the term as used in Part VI of this Article).
} 
structive insiders. ${ }^{26}$ Such a system, I argue, provides the hope of filling in the gaps left by the current "disclose or abstain" system, by encouraging the reflection of certain information in stock market price without disclosure of the actual inside information. Furthermore, this proposal leaves unchanged federal law regarding the trading and tipping activities of corporate insiders and constructive insiders - those parties who have assumed a fiduciary duty to the corporation and its shareholders and who often control the corporation's information flow to the outside world. Accordingly, this proposal avoids the perverse incentives and negative impacts on market efficiency attendant in a system that permits insider trading by such parties.

The reality is that many corporate outsiders who frequently come into contact with valuable inside information are in a contractual relationship with the issuer or its insiders and will be prevented by confidentiality agreements from trading on or disclosing the information acquired during the course of that relationship. This proposal, therefore, does not "legalize" outsider trading so much as transfer the burden of enforcing such agreements from the Commission, which is currently overburdened and whose enforcement of such agreements has been costly and ineffective, to private parties and state courts.

Part VII concludes that, although both the fairness concerns expressed by informational-egalitarians and the efficiency concerns expressed by informational-propertarians are legitimate goals of insider trading regulation, the regulatory proposals advanced by both groups are unlikely to further either fairness or efficiency in any meaningful way. Instead, a more balanced approach that appropriately accounts for the need to weigh incentives for information production and dissemination against the public's right to access such information provides the best hope of furthering these two competing objectives of intellectual property law.

\section{THE INSIDER TRADING PUZZLE-THE FIRST ECONOMIC APORIA}

In this Part, I argue that the controversy and extraordinarily intense feelings engendered by the insider trading debate can be attributed to the fact that information regulation goes to the heart of our notions of fairness and efficiency and of the role of governments and markets in furthering those goals. As will be seen in Part III, however, many of the visceral reactions to information regulation stem from subconscious and flawed beliefs regarding which actions and activities are a part of the "public" sphere, where government intervention to ensure a theoretically level playing field

\footnotetext{
26 Tippees are liable for insider trading under Rule 10b-5 only if they know or have reason to know that the information was given to them in breach of a fiduciary duty. See Dirks v. SEC, 463 U.S. 646 (1983) (finding that Dirks did not violate Rule 10b-5 by trading on information provided by Equity Funding employees, because the employees breached no fiduciary duty to Equity or its shareholders in conveying the information to Dirks).
} 
is favored, and the "private" sphere, where markets are assumed to promote the most efficient outcome and even theoretical equality is not expected.

Information plays a pivotal role in economic analysis. As explained by one commentator: "The role of information in the economic model is stated here in a nutshell: Information is the essential ingredient of choice, and choice among scarce resources is the central question of economics."27 Information's economic role, however, is complex and often contradictory. Specifically, information possesses four economic characteristics that lead to two separate but related "aporia" in information economics. The first aporia, discussed in this Part, arises because information possesses qualities of both extreme nondiminishability (that is, it is a "public good") and extreme nonexcludability (that is, it is a "collective good"). In the case of information regulation, these characteristics are difficult to reconcile and lead to divergent and inconsistent policy implications.

The second aporia, discussed in subpart III.B, arises because information occupies a unique and contradictory role as both a precondition to informed markets and a valuable commodity within those markets, leading to the wellknown "efficiency paradox." Because of these two aporia, the regulation of information and its role in the marketplace are extraordinarily problematic.

\section{A. Information as a Public Good and a Collective Good}

While some commentators have treated the terms "public good" and "collective good" interchangeably, ${ }^{28}$ others have argued that the terms are not only distinct, but, in the case of information, are inharmonious. Professor Harold Demsetz described the difference between a public good and a collective good as follows:

Frequently, there is confusion between the public good concept, as I understand it, which states that it is possible at no cost for additional persons to enjoy the same unit of a public good, and a different concept, that might be identified as a collective good, which imposes the stronger condition that it is impossible to exclude nonpurchasers from consuming the good. ${ }^{29}$

By labeling information a collective good in this Article, I do not mean to imply that it is literally impossible to exclude nonpurchasers, but rather the slightly weaker condition that such exclusion is extremely difficult. ${ }^{30}$ As used in this Article, therefore, the term "public good" refers to goods

\footnotetext{
27 EJAN MACKAAY, ECONOMICS OF INFORMATION AND LAW 107 (1982).

28 See, e.g., ROBERT H. FRANK, MICROECONOMICS AND BEHAVIOR 626 (2000) (noting that public goods "possess, in varying degrees, the properties of nondiminisliability and nonexciudabiliny"); WALTER NICHOLSON, INTERMEDIATE MICROECONOMICS AND ITS APPLICATIONS 612 (1983) (defining a public good as one possessing nonexclusivity and nonrivalness).

29 Harold Demsetz, The Private Production of Public Goods, 13 J.L. \& Econ. 293, 295 (1970).

30 See Nicholson, supra note 28, at 612 ("A good is nonexclusive if it is impossible, or very' costly, to exclude individuals from benefiting from the good.").
} 
possessing some degree of nondiminishability, or nonrivalness, while the term "collective good" refers to goods possessing some degree of nonexcludability. As discussed, information possesses both qualities, making it both a public good and a collective good, a condition sometimes referred to as a "pure public good."

1. Information as a Public Good. Because information is necessary to knowledgeable decision making, information is valuable. Not only are individuals willing to expend their own time, energy, and intellect acquiring information, they also are willing to pay others to produce or acquire information for them. In this sense, information shares similarities with many commonly bought and sold services and physical commodities for which markets have successfully developed. ${ }^{32}$

Unlike most marketable goods and services, however, information is a public good, meaning that it is possible for additional persons to enjoy the same unit of information at no extra cost, although some information may become less valuable as more people have access to it. ${ }^{33}$ As a consequence, information is often misperceived as somehow infinite or limitless-ca gift that can be given without making the giver any poorer." 34 Perhaps for this reason, one often encounters pockets of egalitarian theory in the most unexpected areas, such as the securities markets, when information, rather than some other commodity, is at stake. ${ }^{35}$ In other words, when information is incorrectly regarded as infinite, legal rules mandating a redistribution of information are not perceived to carry the same distributional consequences as would, for example, a legal mandate redistributing wealth, education, or some other asset. ${ }^{36}$

31 FRANK, supra note 28, at 626 (defining collective good, public good, and pure public good). Other examples of goods possessing high degrees of both nonexclusivity and nondiminishability are national defense and mosquito control. Nicholson, supra note 28, at 613, tbl. 21.2. Goods such as fishing grounds or public grazing land, on the other hand, are collective goods because they are nonexclusive, but diminishable. In contrast, bridges and highways are public goods, because they arc non-diminishable (at least to the point of congestion), but are exclusive. Id.

32 Kenneth J. Arrow, Economic Welfare and the Allocation of Resources for Invention, in THE RATB AND DIRECTION OF INVENTIVE ACTIVITY: ECONOMIC AND SOCIAL FACTORS 609, 614 (Nat'l Burcau of Econ. Research ed., 1962) (stating that "information will frequently have an economic value" and arguing that "it might be expected that information will be traded in").

33 Demsetz, supra note 29, at 295 (defining "public good"); Paul A. Samuelson, The Pure Theory of Public Expenditure, 36 REv. ECON. \& STAT. 387 (1954) (opining that with regard to public goods, "each individual's consumption of such a good leads to no subtraction from any other individual's consumption of that good").

34 Boyle, supra note 7, at 1438 ("I explain Pythagoras' theorem to you. . . A Afterwards, I seem no poorer in the sense that we both have the knowledge.").

35 See Part IV infra (discussing informational-egalitarianism in the securities markets).

36 Aoki, supra note 14, at 1330 (noting the "distinct but strange egalitarian attitudes with which courts and legislatures seek to deal with informational disparities in all kinds of legal disputes by ordering redistribution of access to information, in ways that they would never do with regard to other types of inequalities"); Boyle, supra note 7, at 1438-39 ("Perhaps this is one of the reasons that in moments of high moral or ideological conflict, we often reach for a solution that involves giving the parties more 
When playing its public good role, therefore, information is a part of the informational-egalitarian public sphere, where it is viewed as an infinite resource that should be shared and spread as widely and as equally as possible. Accordingly, informational-egalitarians are relatively unconcerned with creating economic incentives for the production of information and instead are concerned primarily with fairness and equality. ${ }^{37}$ They are frequently troubled by notions that some members of society may be monopolizing or withholding information, or that some members of society have access to information unavailable to all. Consequently, informationalegalitarians often argue that the law governing insider trading should favor fairness over efficiency.

This informational-egalitarian attitude is reflected in the First Amendment to the United States Constitution. ${ }^{38}$ The Constitutional framers believed keenly in the widespread dissemination of thoughts, ideas, information, and expression and felt strongly that informational asymmetries between citizens of the new nation would prevent full and knowledgeable debate and the realization of the goals of democracy. ${ }^{39}$ This view is also reflected in early property law, which tended to view information as something that could not be owned, and in much insider trading regulation and commentary. ${ }^{40}$

\section{Information as a Collective Good}

a. The Collective Good "Problem."--In addition to being a public good, information also presents the nonexclusivity problems of a collective good, in that permitting access to those paying for the use of the information while excluding others is difficult. ${ }^{41}$ Neoclassical economic

information. If we are thinking of information as a resource that is infinite in this sense, then the distribution of wealth does not seem to have changed.").

37 See Roberta S. Karmel, Outsider Trading on Confidential Information-A Brcach in Scarch of a Duty, 20 CARDOZO L. REV. 83, 111 (1998) (arguing that "the federal securities laws, and panticularly the anti-fraud provisions, were primarily enacted to promote investor confidence in the faimess and honesty of the markets, and only secondarily to achieve efficiency in stock market pricing."); Levmore, supra note 23, at 118 (discussing "disclose or abstain" proponents and their coneem with faimess).

38 See U.S. CONST. amend. I "Congress shall make no law respecting an establishment of religion, or prohibiting the free exercise thereof; or abridging the freedom of speech, or of the press; or the right of the people peaceably to assemble, and to petition the government for a redress of grievances.").

39 Aoki, supra note 18, at 11 ("Open access to all kinds of new and old information, ideas and faets is the premise on which the First Amendment rests."); Pamela Samuelson, Information as Property: Do Ruckelshaus and Carpenter Signal a Changing Dircction in Intcllcctual Propcry' Lan?, 38 CATi. U. L. REV. 365, 372 (1989) ("The drafters of the Constitution, edueated in the Enlightenment tradition, shared that era's legacy of faith in the enabling powers of knowledge for society as well as the individual. They viewed free access to knowledge as an essential step in building the fledgling nation.").

40 See subpart V.C infra (discussing the traditional U.S. legal view that information could not bs owned) and Part IV infra (discussing informational-egalitarianism in the insider trading context).

41 See Arrow, supra note 32, at 614-15 (discussing the inappropriability of infomation); Samuelson, supra note 39, at 369 ("[I]nformation is very difficult to maintain in any exclusive manner unless kept secret by its discoverer or possessor."). 
theory holds that this inappropriability of information prevents the information producer from capturing the full benefits of production, leading to decreased incentives for the production of information and a potential underproduction of the resource. ${ }^{42}$

This inappropriability is exacerbated by the fact that information can usually be widely disseminated at a low marginal cost. ${ }^{43}$ In other words, although the cost of the initial production of information may be very high, the costs of duplication are typically low. ${ }^{44}$ Biomedical researchers, for example, may engage in many years of experimental research before discovering the cure for a disease. Similarly, an author or composer may spend a lifetime developing an original work. The formula, novel, or symphony, however, can usually be copied and disseminated quickly and at a comparatively low cost. This increases the difficulty initial information producers face in appropriating the benefits of production. Traditional economic theory predicts that suppliers will recognize the inability to profit from information production due to this combination of inappropriability, high initial fixed costs, and low marginal cost of dissemination and will not enter the market, resulting in an underproduction of information. ${ }^{45}$

To see how the problem of inappropriability affects information, suppose a law student has somehow attained the answers to her securities regulation professor's final exam and would like to profit from this information by selling it to other members of her ninety-student class. ${ }^{46}$ If the class is graded on a curve, however, the information becomes less valuable as more people have access to it. Once she sells the information to a fellow student, how can she be assured that the student will not resell or freely disseminate the information to other class members, undercutting the first student's sales and profits? Likewise, how can each purchaser be assured that the answers she buys will remain relatively secret, and therefore valuable, and will not be further disseminated to other purchasers? Without some means for both sellers and buyers of information to exclude others from its use, they cannot be assured of the quality and value of the product they are exchanging and will be reluctant to trade in information absent some credible guarantee as to value.

b. The Tragedy of the Commons.-The discussion in subsection II.A.2.a of information as a collective good is intricately related to the voluminous scholarship on the "tragedy of the commons." In fact, it has been

42 See Robert CoOter \& ThOMas Ulen, LAW AND ECONOMics 112-13 (1988); Richard A. POSNER, ECONOMIC ANALYSIS OF LAW 36 (5th ed. 1990); Arrow, supra note 32, at 615.

43 See COOTER \& ULEN, supra note 42, at 112-13; Arrow, supra note 32, at 614-15.

44 See COOTER \& ULEN, supra note 42 , at 112-13.

45 POSNER, supra note 42 , at 36.

46 MACKAAY, supra note 27 , at 114. 
explicitly noted that the "'field of ideas' bears a great similarity to a common."

Neoclassical economics holds that, because common ownership prevents internalization of the full costs and benefits of an activity, it is likely to result in the tragedy of overuse and undersupply of limited resources. In other words, when common rights to use a limited resource are shared, there is an incentive for overconsumption. Similarly, when a common obligation to provide a resource is shared, there is an incentive to underproduce. ${ }^{48}$ The classic "tragedy of the commons" was first illustrated by Professor Garrett Hardin through the example of cattle herders using a common pasture. ${ }^{49}$ Because the benefits of adding an extra cow to a herd accrue only to the individual herdsman, while the costs of each extra cow are shared by all of the herdsmen (that is, the costs are not fully internalized), each herdsman will be tempted to increase the size of his herd as much as possible. ${ }^{50}$ In other words, although it is in the collective best interest of all cattle herders to limit the size of the herds, no herdsman will want to be left in the predicament of not increasing his herd size while others increase theirs. This would cause him to suffer all of the harm of overcrowding, but reap none of the benefits. Because each herdsman will follow this same logic and increase the size of his herd, tragedy is the predicted result. ${ }^{51}$ If war, disease, or other external factors do not limit the growth of the herds, then eventually the commons will become over-

47 Justin Hughes, The Philosophy of Intellectual Propert!, 77 GEO. L.J. 287, 315 (1988).

48 PAUL MiLgRom \& JOHN ROBERTS, ECONOMIC, ORGANizATION \& MANAGENIENT 294 (1992).

49 Garrett Hardin, The Tragedy of the Conmons, 162 SCIENCE 1243-48 (1968), reprinted in PERSPECTIVES ON PROPERTY LAW 132, 133 (Robert C. Ellickson et al. eds., 1995).

so Id. at 133. Theoretically, tragic overuse and underuse could be avoided if tronsaction costs did not prevent the interested parties from contracting or otherwise bargaining to reach the optimal use of the resource. See R.H. Coase, The Problem of Social Cost, 3 J.L. \& Econ. 2-8 (1960); Harold Demsetz, Toward a Theory of Property Rights, 57 AM. ECON. REv. 347, 348 (1967). Subsequent scholars have demonstrated, however, that even absent transaction costs, cognitive biases such as framing and endowment effects may prevent the parties from reaching the efficient result. See gencrally Massisto Platelli-Palmarini, Inevitable Illusions: How Místakes of ReAson RULE OUR MiNdDS (1994) (discussing a wide variety of psychological tendencies affecting decision making); Jeffrey J. Rachlinski, Gains, Losses, and the Psychology of Litigation, 70 S. CAL. L. REv. 113 (1996) (discussing the impact of risk and framing on decision making); Jeffrey J. Rachlinski \& Forest Jourden, Remedies and the Psychology of Ownership, 51 VAND. L. REV. 1541 (1998) (discussing the endowment effect and its impaet on decision making).

${ }^{51}$ Hardin, supra note 49, at 133. Because the herdsmen are locked into a prisoner's dilemma, some of the same methods of avoiding defection in that game, such as the existence of repeat players who find it mutually beneficial to cooperate, can also help avoid the tragedy of the commons. Sce AvI:Aash $K$. Dixit \& BarRy J. Nalebuff, Thinking Strategically: The CoMpetimive Edge in Business, POLITICS, AND EVERYDAY LIFE 348-49 (1991). Similarly, Professor Robert Ellickson has angued that members of a closely-knit community will cooperate to avoid the tragic result predicted by Hardin. Sce ROBERT C. ELLICKSON, ORDER WITHOUT LAW 167-83 (1991) (discussing the private ordering and enforcement mechanisms that develop in small, closely-knit groups); Roben C. Ellickson. Property in Land, 102 YALE L.J. 1315, 1320 (1993) [hereinafter Ellickson, Properyy] (same). 
crowded and unable to support the cattle grazing there. ${ }^{52}$ As stated by Professor Hardin:

Each man is locked into a system that compels him to increase his herd without limit-in a world that is limited. Ruin is the destination toward which all men rush, each pursuing his own best interest in a society that believes in the freedom of the commons. Freedom in a commons brings ruin to all. ${ }^{53}$

Although Hardin's original tragedy of the commons discussed the danger that scarce resources held in common will be overconsumed, commons resources also may tend to be undersupplied. ${ }^{54}$ For example, Professor Harold Demsetz demonstrated that the tragic nature of commons property resulted from the failure of such a system to internalize fully the costs and benefits of individual actions. ${ }^{55}$ When the externality generated by an activity is a cost, such as overcrowding in a pasture and the resultant damage to the cattle herd, overuse is the likely result. ${ }^{56}$ When, however, the externality generated by an activity is a benefit, such as the potential increased fur trade resulting from the husbanding of valuable fur-bearing animals, underuse may result. $^{57}$ If individuals are unable to internalize the full benefits of information production, there are reduced incentives to incur the costs necessary to create information, resulting in potential underproduction of the resource.

\section{c. Property Rights as a Resolution to the Collective Good Di-} lemma.-Subsections II.A.2.a and b presented the neoclassical economic argument that common ownership of limited resources is inefficient because those resources are likely to be either overconsumed or undersupplied. This subsection presents the proposed neoclassical economic resolution to the collective good problem: a system of private ownership of limited resources.

Applying neoclassical principles to information jurisprudence has led many observers to argue that property rights in information are necessary to avoid the potential problems of underproduction and inefficient allocation of information. ${ }^{58}$ Consequently, when playing its collective good role, in-

52 Hardin, supra note 49, at 133.

53 Id.

54 MILGROM \& ROBERTS, supra note 48, at 294; POSNER, supra note 42, at 37; Carol Rose, The Comedy of the Commons: Custom, Commerce, and Inherently Public Property, 53 U. CHI. L. REV. 711, 712 (1986) ("[W]hen things are left open to the public, they are thought to be wasted by overuse or underuse.").

S5 Demsetz, supra note 50 , at 348 .

56 Id. at 351 (demonstrating that the failure to internalize all of the costs of hunting could result in overhunting and a depletion of game valuable to the fur trade).

57 Id. at 352 (demonstrating that, until American Indians had the ability to prevent poaching by others, there was no incentive to spend the resources necessary to engage in animal husbandry).

${ }^{58}$ See, e.g., Anthony T. Kronman, Mistake, Disclosure, Information, and The Law of Contracts, $7 \mathrm{~J}$. LEgal STUd. 1, 2 (1978); William M. Landes \& Richard A. Posner, An Economic Analysis of Copyright Law, 18 J. Legal STud. 325, 328 (1989); Macey, From Fairness to Contract, supra note 9. See Part V infra (discussing informational-propertarianism). 
formation is a part of the informational-propertarian private sphere-a finite and valuable commodity protected by private property rights. This role is in conflict with information's previously discussed role as a public goodan infinite, equally shared, and widely dispersed part of the informationalegalitarian public sphere. In contrast to the equality of access expected when information is viewed as a public good, information as a collective good is viewed as part of the informational-propertarian private sphere where individuals are not only expected, but encouraged, to profit from their informational advantages. Informational-propertarians, therefore, are concerned primarily with the efficiency of legal rules as a spur to information production and allocation, and only secondarily with concerns of fairness or equality. ${ }^{59}$

As part of the informational-propertarian private sphere, information becomes just another valuable commodity that is bought, sold, and otherwise acquired with varying degrees of skill and success by marketplace actors. As Professor Pamela Samuelson stated:

As with other goods obtained through an expenditure of labor, information often has a substantial exchange value. Those who do not have it may be willing to pay large sums to acquire it. This was true long before the Information Age commenced and will continue to be true in any post-Information Age society.

While the informational-egalitarian view of the public sphere is reflected in the First Amendment, the informational-propertarian view of the private sphere is reflected in the patent and copyright clause of the Constitution, which grants Congress the power: "To promote the Progress of Science and useful Arts, by securing for limited times to Authors and Inventors the exclusive right to their respective Writings and Discoveries." ${ }^{\circ 1}$ In fact, U.S. patent and copyright law are largely based on the perception that authors, inventors, and other producers of creative work will not produce, and that publishers and other distributors of such works will not disseminate, the optimal amount of inventive and artistic labor in the absence of property rights. ${ }^{62}$ U.S. patent and copyright law thus seek to straddle the line between information in the public and the private spheres, by granting to authors and inventors property rights in their inventions and "expressions," respectively, but not in the ideas themselves. ${ }^{63}$

59 See Michael Dooley, Enforcement of Insider Trading Restrictions, 66 VA. L. REv. 1, 64 (1980) (arguing that efficiency, rather than faimess, should be the goal of insider trading regulation); Levmore, supra note 23, at 118 (discussing the "free market" approach to insider trading regulation and its focus on market efficiency).

${ }^{60}$ Samuelson, supra note 39, at 370.

61 U.S. CONST. art. I, § 8, cl. 8.

${ }^{62}$ Landes \& Posner, supra note 58, at 328.

${ }^{63}$ Id. at 326 ("Copyright protection ... trades of the costs of limiting access to a work against the benefits of providing incentives to create the work in the first place."); Samuelson, supra note 39, at 372 (noting that "copyright protects a writing's 'expression, not the facts contained in the writing. A patent does not protect an inventor's discovery; it only prevents the invention from being 'practieed' by others during the seventeen year life of the patent without the patentee's permission."). Reeent commentators 
The informational-propertarian view is also reflected in some aspects of the common law of nondisclosure and in some insider trading law and commentary. ${ }^{64}$ Subpart V.A of this Article, however, explores cogent arguments by some economists and legal commentators that private ownership of information may lead to an inefficient use of resources, resulting in either an under- or overproduction of information.

\section{B. Section Summary}

Insider trading inspires immediate and passionate reactions among legal scholars, regulators, and the general public. Yet, despite the extraordinary intellectual resources expended on resolving the insider trading puzzle, observers remain squarely divided into two camps. Those who propose solutions based on fairness considerations often accuse their opponents of callousness and of excessive reliance on notions of economic efficiency without due regard to justice and equality. ${ }^{65}$ Those who propose solutions based on economic efficiency often accuse their opponents of foolishness or naiveté. ${ }^{66}$

In this Part, I have endeavored to uncover the root of the fairness/efficiency controversy in the context of insider trading regulation. Information's dual role as both a public good and a collective good leads to a seemingly irreconcilable aporia. Consequently, information regulation seems to engender a tension between the desire to foster fairness, often envisioned as some type of informational equality, and the desire to foster efficiency, which often takes the form of granting a property right to the creators of information in an attempt to encourage production. Any attempt to further fairness by placing marketplace actors on a more equal informational footing, it is argued, necessitates a tradeoff of decreased incentives for information production, and the danger of a less efficient market. Any attempt to incentivize production by permitting marketplace actors to profit from their informational advantages, it is argued, necessitates a tradeoff of less informational equality. As discussed in Part III, however, these vis-

have argued that judges are increasingly applying patent and copyright law in a manner that protects information rather than expression and have criticized these perceived grants of rights in new types of property as detracting from the public domain of ideas. See subpart V.C infra.

64 See Part V infra (discussing the property rights based approach to insider trading liability).

65 See, e.g., Roberta Karmel, The Relationship Between Mandatory Disclosure and Prohibitions Against Insider Trading: Why a Property Rights Theory of Inside Information is Untenable, 59 BRook. L. REV. 149, 168 (1993) (reviewing arguments by Professors Jonathan R. Macey and Bernhard Bergmans that inside information should be regulated through a property rights approach, and arguing that " $[t]$ he view that inside information is a property right that insiders should be permitted to exploit is morally obnoxious and legally unsound").

66 See, e.g., MANNE, INSIDER TRADING, supra note 9, at $233 \mathrm{n} .42$ (referring to arguments that insider trading is unfair as "it's just not right propositions" in honor of "an anonymous lady law student, who, during a classroom discussion of the subject, stamped her foot and angrily declaimed, 'I don't carc; it's just not right."”); Manne, supra note 6, at 549 ("Morals, someone once said, are a private luxury. Carried into the arena of serious debate on public policy, moral arguments are frequently either sham or a refuge for the intellectually bankrupt."). 
ceral reactions to insider trading stem from subconscious and flawed beliefs regarding public/private distinctions, rendering the faimess/efficiency debate hollow, and the resolutions that stem from that debate unlikely to foster either faimess or efficiency goals.

\section{DECONSTRUCTING THE FAIRNESS/EFFICIENCY DEBATE}

\section{A. The Public/Private Distinction}

The economic analysis of information in Part II of this Article is intricately related to the traditional liberal distinction between the public and private spheres. ${ }^{67}$ As discussed above, due to information's qualities as both a public good and a collective good, it is sometimes perceived as a part of the informational-egalitarian public sphere, where it is viewed as an infinite resource that should be shared and spread as widely and as equally as possible, and at other times it is perceived as a part of the informationalpropertarian private sphere, where it is conceived of as a finite commodity requiring protection through property rights. Furthermore, the propertization of information advocated by neoclassical economic scholars as a potential resolution to the collective good nature of information attempts to separate through private property rights certain information from the public "intellectual commons" and move it into the private sphere. This, however, creates a tension with information's more public role as a necessary condition to market efficiency.

This categorization of information as either public or private comports with traditional, mainstream legal thought, which posits the existence of a

67 The notion that false public/private distinctions pervade mainstream legal and politieal discourse is one of the hallmarks of Critical Legal Studies (CLS). Many readers may be suprised to leam that, despite the frequent tensions between CLS and law and economics, the two sehools of thought share a similar rejection of the alleged neutrality and objectivity of legal rules. Sce MARk Kelatan, A Guide TO CRITICAL LEGAL STUDIES 114 (1987) (noting that, because much CLS literature is critical of law and economics scholarship, CLS is often perceived as anti-law and cconomics); Duncan Kennedy \& Frank Michelman, Are Property and Contract Efficient?, 8 HOFsTRA L. REv. 711 (1980) (criticizing Professor Richard A. Posner's economic approach to private property). Professor Kelman, however, expresses his own opinion that "the relationship between CLS and Law and Economics is in faet quite intimate."). KeLMAN, supra, at 115.

Similarly, Professor Edward L. Rubin has explored the possibility of a convergence between "second generation" CLS scholars (such as critical race theorists, feminist legal theorists, and gay legal studies scholars) and "second generation" law and economics scholars (sometimes referred to as "new Chicago School" theorists). See generally Edward L. Rubin, The New Legal Process. The Synthesis of Discourse, and the Microanalysis of Institutions, 109 HARV. L. REV. 1393, 1403 (1996) (discussing the possibility of a convergence of CLS and law and cconomics); sce also NICHOLAS MERCURO \& STEVE: G. MEDEMA, ECONOMICS AND THE LAW FROM POSNER TO POST-MODERNISM 157-70 (1997) (discussing CLS in a book entitled Economics and the Law, implying a close relationship between the two schools of thought). 
fairly sharp distinction between the spheres of public and private life. ${ }^{68}$ According to traditional legal thought, the private sphere is the world of contract, deliberate choice, and individual autonomy. ${ }^{69}$ Consequently, inequalities, including inequalities in the possession of information, are tolerated in the private sphere as being the product of individual choice or consensual contract. ${ }^{70}$ One of the primary fears of mainstream liberal political philosophy, therefore, is the unrestrained incursion of the state into the private realm. ${ }^{71}$ The law is the means by which we safeguard the private realm from such public invasions. ${ }^{72}$

In contrast to the competitive, individualistic private sphere, the public sphere is characterized by community and equality. For example, in the liberal state there are no formal state-mandated advantages restricted to those belonging to a certain social class, occupation, or rank, although, as discussed below, there may be numerous informal advantages reserved for such persons. ${ }^{73}$ In the liberal state, everyone is entitled to an equal vote, regardless of wealth, social status, or educational background. ${ }^{74}$ In the public sphere, which is characterized by public debate and the free exchange of ideas, information and knowledge are vital preconditions to a healthy democracy, enabling citizens to exercise their rights and check government overreaching. $^{75}$

The deconstruction of the public/private distinction is intimately related to the forgoing analysis of the economics of property. Property is frequently defined as a "bundle of rights."76 One of the sticks contained

${ }^{68}$ KELMAN, supra note 67, at 102 ("The mainstream right-centrist legal position ... [i]s that there is a fairly distinct line between the domain of intentional choice and freedom (private life, contract) and the domain of coerced choicelessness (public life, mandatory law, subjection to political sovereignty)."); Boyle, supra note 7, at 1433-34 (describing the public/private distinction as a central theme in the modern liberal state).

69 See Boyle, supra note 7, at 1433-34.

70 See id.

71 Id. at 1434 ("The central fear of the liberal political vision is that unrestrained state power will invade the private sphere.").

72 Id. ("By policing the lines between public and private and between citizens and other citizens, the law offers us the hope of a world that is neither the totalitarian state nor the state of nature.").

73 Id. at 1433; KARL MARX, On the Jewish Question, in KARL MARX EARLY WRITINGS 11 (T.B. Bottomore ed., 1964).

74 Boyle, supra note 7, at 1433.

75 Id. at 1437. James Madison explained the point best: "A popular Government, without popular information, or the means of acquiring it, is but a Prologue to a Farce or a Tragedy; or, perhaps both. Knowledge will forever govern ignorance; And a people who mean to be their own Governors, must arm themselves with the power which knowledge gives." Letter from James Madison to W.T. Barry (Aug. 4, 1822), in THE COMPLETE MADISON 337, 337 (Saul K. Padover ed., 1953), quoted in Boyle, st1. pra note 7, at 1437; see also Aoki, supra note 18, at 11-12 ("This 'informationally cgalitarian' atmosphere is a crucial feature of the public world. Informational disparities between citizens are seen as flaws to be corrected only through wider access to even more speech.").

${ }^{76}$ See infra note 77 (describing property as "a bundle of rights"); see also infra note 165 (discussing the other rights in this "bundle"). 
in that bundle is the right to the exclusive use of the property-in other words, the right to use the property as the owner sees fit and to prevent others, including the government, from interfering with that use. ${ }^{7 f}$ Property thus creates a "zone of privacy"78 that, in mainstream liberal thought, constitutes the line demarcating the private from the public realm. It is through property rights that the private world is protected from intrusion by outsiders, including the government. ${ }^{79}$

Accordingly, situations, rights, or objects considered "private" are often legally protected by a private property right. For example, one's home, one's money, and, sometimes, one's information are protected by some version of a property right. ${ }^{80}$ In contrast, situations, rights, and objects considered "public" are not separated from the public domain by a property right and instead are presumed to be shared equally. For example, voting rights, access to the criminal justice system, some beaches and waterways, ${ }^{81}$ and, sometimes, information fall within this realm. ${ }^{82}$ Information, therefore, unlike most other goods, sometimes rests in the private realm and at other times in the public, resulting in an inconsistent and confusing legal regime.

Karl Marx was one of the first political theorists to highlight the superficiality of the public/private distinction in liberal political states such as the United States. ${ }^{83}$ In On the Jewish Question, Marx criticizes Bruno Bauer for his failure to "examine the relation between political emancipation and human emancipation."34 Marx highlights the shortcomings of mere political emancipation by pointing out that "[t]he limits of political emancipation appear at once in the fact that the state can liberate itself from a constraint without man himself being really liberated; that a state may be a free state without man himself being a free man."

77 See Kaiser Aetna v. United States, 444 U.S. 164, 176 (1979) (describing the right to exelude others as "one of the most essential sticks in the bundle of rights that are characterized as propenty"); COOTER \& ULEN, supra note 42, at 91. See also infra note 101 (diseussing the imponanee that propeny" rights scholars attach to the right to exclude).

${ }^{78}$ See COOTER \& ULEN, supra note 42, at 91-93.

79 Aoki, supra note 18, at 11 ("“U]nder traditional enlightenment-based liberal political social theory, the idea and institution of private propenty demareates a contradictory border between individual freedom of action and the threat of coercion by the stote."); Aoki, supra note 14, at 1318.

${ }^{80}$ Copyright law, for example, traditionally protects "expressions," but not ideas. Breyer, supra note 13, at 282. Trade secret law may restrict certain uses of information, but generally avotds charaeterizing information itself as property; see also subpan V.C infra (diseussing criticisms by some legal observers of a perceived increase in information commodification in recent years).

81 Rose, supra note 54, at 713-14.

82 See subpart V.C infra (noting the general reluctance of the Ameriean legal system to recognize property rights in information).

83 See generally MARX, supra note 73.

84 Id. at 8.

85 Id. at 10-11. 
According to Marx, political emancipation fails to free the individual from state oppression because, although a society may have mandated political emancipation, there is no emancipation of the individual from the civil state. Consequently, unless inequalities are eliminated from the civil state, even a politically emancipated individual is not free. ${ }^{86}$

Post-Modernist scholars, building on Marx's ideas, have criticized attempts to distinguish public life from private life by arguing that these socially constructed divisions mask substantive decisions to tolerate inequalities in the allocation of wealth, power, justice, and information. For example, some legal theorists have noted the control the state exercises in determining the conditions precedent to valid contracting, arguing that the legal rule that a contract induced through physical force is invalid actually represents a coercive state intervention in the area of contract that entails significant allocative consequences. In other words, such a rule reduces the contracting power of those more capable of wielding physical force. ${ }^{87}$

Society's refusal to tolerate some inequalities in bargaining power, such as physical strength or access to force, yet accept others as natural, such as differences in wealth or knowledge, is thus offered as evidence of the socially constructed nature of distinctions such as public and private. ${ }^{88}$ The public/private distinction, it is argued, ultimately collapses with the realization that a contract does not even become a contract without state intervention. In other words, absent a conscious state determination to treat certain expressions of mutual commitment as legally binding, the "private" world does not even exist. ${ }^{89}$

According to many legal theorists, therefore, the distinctions of public and private are nothing more than hollow stereotypes masking society's paradoxical willingness to tolerate inequality in certain realms and not in others. As Professor James Boyle stated:

Thus we have equality, but only inside the public sphere. Citizens are equal, but only in their capacities as citizens, not as private individuals. Each is guaranteed an equal vote, but not equal influence. We draw a line around certain activities-voting, appearing in court, and so on-and guarantee equality within this realm. Outside that line is the private sphere, the world of civil society. It is the

\footnotetext{
${ }^{86}$ Id. at 12. As Marx stated:
}

The state abolishes, after its fashion, the distinctions between birth, social rank, education, occupation, when it decrees that birth, social rank, education, occupation are non-political distinctions; when it proclaims, without regard to these distinctions, that every member of society is an equal partner in popular sovereignty, and treats all the elements which compose the real life of the nation from the standpoint of the state. But the state, nonetheless, allows private property, education, occupation, to act after their own fashion, namely as private property, education, occupation, and to manifest their particular nature. Far from abolishing these effective differences, it only exists so far as they are presupposed.

Id.
${ }^{87}$ KELMAN, supra note 67, at 103.
88 Id. at 103-05.
${ }^{89}$ Id. at 105 . 
private sphere that contains all of the real differences between peopledifferences of wealth, power, education, birth, and social rank. ${ }^{90}$

Society's conception of rights, justice, and access thus depends on whether an activity is envisaged as part of the public or private realm. ${ }^{9 !}$ Higher education, medical care, housing, wealth, and social status, to name just a few, are contained in the private sphere where there is no guarantee of equality of access, or, for that matter, to even minimal access. ${ }^{92}$ Voting and, to a limited extent, legal representation are contained in the public sphere where equality is expected. 95 Unlike most other valuable objects, therefore, information lies particularly close to the imagined public/private dividing line. Because property is the means by which the private world is separated from the public one, legal commentators sometimes advocate-and the law sometimes mandates-the protection of information through private property rights and sometimes does not, depending on erroneous perceptions as to whether the activity in question falls primarily in the private or public realm. As a result, insider trading regulation is inconsistent and incoherent.

How is this public/private determination made, however, with regard to an item, such as information, that society considers neither inherently public nor inherently private? In other words, how is the determination made as to when information will be considered public, as opposed to private? The following subpart discusses one means by which society attempts to compartmentalize information into either the public or private sphere.

\section{B. Author Reasoning and the Romantic Author Ideal}

As discussed in subpart III.A, unlike most other goods, information is sometimes perceived as part of the informational-egalitarian public sphere, where individuals are presumed to be entitled to some level of equality, and sometimes as part of the informational-propertarian private sphere, where people are not only expected, but encouraged, to profit from their informational advantages. Intellectual property scholars have argued that the pub-

\footnotetext{
90 Boyle, supra note 7, at 1433.

91 Id. at 1434-35.

92 Id. at 1435.
}

93 Id. (explaining that legal representation is at least partly contained in the public sphere becouse criminal defendants are constitutionally entitled to an attomey when being tried for erimes that carry the possibility of a substantial jail term, regardless of whether or not the defendant has the resources to pay for legal representation). Professor Boyle illustrates the public/private dichotomy and the law's role in preserving and promoting the distinction through the example of ton and criminal assault laws. Ton law, being a division of civil law, lies in the private realm and thus tolerates numerous inequalities among individuals. For example, an investment banker injured by a negligent driver will collect for more damages in the form of lost wages than would a homeless plaintiff. Criminal law on the other hand tolerotes no such distinctions. The punishment for one guilty of criminal assault is the same regardless of whether the victim is rich or poor. All crime victims are legally entitled, but may not actually receive, the same protections. Our notions of fundamental faimess are oftended by assertions that the reality may be otherwise. Id. at 1433-35. 
lic/private sphere tensions inherent in information regulation are often resolved through author reasoning, that is, by reference to an image of the "romantic author" whose labor and creativity should be rewarded and encouraged through the grant of private property rights in the information she produces or discovers. ${ }^{94}$

It has been argued, for example, that copyright and patent law attempt to straddle this imagined division between the public and private spheres by reference to the image of the romantic author. In tracing the rise of intellectual property rights in Germany, Professor Martha Woodmansee notes that during the eighteenth century the image of the author evolved from that of a simple craftsman to that of an original creator. ${ }^{95}$ It is this Lockean concept of the author as one who, through his labor and creativity, fashions original works from raw material that justifies the endowment of property rights in the information creator. ${ }^{96}$

Copyright law thus arguably employs the romantic author notion as a means of resolving potential tensions between information in the public and information in the private spheres. ${ }^{97}$ When the information creator's work is not considered sufficiently creative or original, there is no romantic author and, consequently, no property right. ${ }^{98}$ When, however, the information crea-

94 Aoki, supra note 18, at 26-27; Boyle, supra note 7, at 1418. But see infra note 96 (discussing criticisms of the theory that author reasoning explains the commodification of information).

95 Martha Woodmansee, The Genius and the Copyright: Economic and Legal Conditions of the Emergence of the 'Author, ' 17 EIGHTEENTH CENTURY STUD. 425, 427 (1984).

96 Id. at 427 ('“'Inspiration' came to be explicated in terms of original genius, with the consequence that the inspired work was made peculiarly and distinctively the product-and the property-of the writer."). John Locke argued that property rights originated by natural law when a person applied his labor to an item, thus removing it from the public domain. JOHN LOCKE, 2 TWO TREATISES OF GOVERNMENT 134 (Thomas I. Cook ed., 1947) (1698) ("Whatsoever then he removes out of the state that nature hath provided and left it in, he hath mixed his labour with, and joined to it something that is his own, and thereby makes it his property."). Locke imposed only two conditions on this theory. First, one's labor only justifies removal of a good from the public domain "where there is enough, and as good left in common for others." Id. Second, one can only acquire a property right in the amount of a good that he could make use of and is not entitled to allow goods to go to waste. Id.

There is currently a lively ongoing debate among intellectual property law scholars regarding whether recent expansions of intellectual property are primarily attributable to neoclassical economics or to natural rights-based philosophies. See, e.g., Julie E. Cohen, Lochner in Cyberspace: The New Economic Ortohodoxy of "Rights Management," 97 MICH. L. REv. 462, 474 (1998) (arguing that scholars following a Lockean justification for intellectual property express more concern for protecting the public domain of ideas than do scholars advancing neoclassical economic justifications, who tend to favor strong intellectual property rights); Mark A. Lemley, Romantic Authorship and the Rhetoric of Property, 75 Tex. L. REV. 873 (1997) (reviewing and rejecting James Boyle's romantic author theory and arguing instead that the growing propertization of information is best explained by reliance on neoclassical economic theory); Netanel, supra note 14, at $307 \mathrm{n} .97$ (arguing that reliance on neoclassical economics explains the recent growth of intellectual property rights much better than does Boyle's natural rights-based theories of romantic authorship). I argue in this Article that both theories are at work in the insider trading debatc.

97 Aoki, supra note 18, at 26; Boyle, supra note 7, at 1470.

98 A frequently cited example is Feist Publ'ns, Inc. v. Rural Tel. Serv. Co., 499 U.S. 340 (1991). In Feist, the Supreme Court refused to extend copyright protection to the creators of a white pages compi- 
tor's work is considered sufficiently original, the work is protected with a property right. ${ }^{99}$ The romantic author ideal is also frequently visible in the insider trading context, where it generally takes the form of labeling some information discoveries as socially useful research and others as unproductive.

\section{INFORMATIONAL EGALITARIANISM-THE FAIRNESS ARGUMENT}

Parts IV through VI situate insider trading regulation within the larger body of intellectual property law. In doing so, I contend that the law governing insider trading is merely a means of allocating property rights in valuable information. While some commentators have criticized this approach by arguing that the purpose of federal securities laws is to protect investors and not to protect property rights in valuable information, ${ }^{160}$ such criticisms fail to appreciate the following points: first, that any governmental approach to insider trading-from allowing all such trading to forbidding it-constitutes an intellectual property regime; and second, that an intellectual property rights regime is not necessarily antithetical to the interests of investors. Consequently, instinctive reactions as to the appropriateness of property rights as applied to inside information should be discarded in favor of an analysis that seeks to determine in which party the property right in valuable inside information should reside.

There are at least three potential allocations of the property right in valuable inside information. ${ }^{01}$ First, as proposed by informational-

lation of names, phone numbers, and addresses-despite the fact that the creators had mixed their labor in the Lockean sense with the raw materials and that the white pages presented classic collective goods problems. Feist, 499 U.S. at 345, 363 (arguing that "the sine qua non of copyright is originality" and that the creators of the white pages at issue had applied "insufficient creativity to make it original"); Peter Jaszi, On the Author Effect: Contemporany Copyright and Collctive Creativisy, 10 Caroozo ARTS \& ENT. L.J. 293, 302 (1992) ("[Feist] wears its values on its sleeve; from first to last, its thetoric proceeds from unreconstructed faith in the gospel of Romantic "authorship."').

99 Professor Boyle further argues that the rather puzzling case of blackmail can also be explained by reference to the romantic author ideal. Boyle, supra note 7, at 1418-19. The case of blackmail is puzzling because revealing the acquired information would be perfectly legal absent an attempt to extract compensation in exchange for silence. See James Lindgren, Unraveling the Paradox of Blackmail, 84 COLUM. L. REV. 670, 670-71 (1984) ("I have a legal right to expose or thresten to expose the crime or affair, and I have a legal right to seek a job or money, but if I combine these rights it is blackmail."). According to Professor Boyle, because there is no identifiable romantic author in the blackmail context whose originality and effort must be rewarded through the grant of propenty rights, informotion used for the purpose of blackmail is relegated to the private sphere of personal life, home, and family, where others are excluded from intrusion. Boyle, supra note 7, at 1470. Legal scholars have also explained the bletkmail paradox on other grounds. For a thorough and insightful review and rejection of these attempts, sse Lindgren, supra, at 670-71, 680-701 (surveying the blackmail literature and coneluding that the blackmail prohibition is best explained by its "triangular structure"-that is, by its impzet on third parties).

${ }^{100}$ See Karmel, supra note 65, at 152; Karmel, supra note 37, at 113.

101 I use the concept of property rights in this Article in a muher unconventional sense, albeit one that has gained acceptance among insider trading scholars. Insider trading seholars have used the concept of property rights in the following two ways: either the owner of information may be permitted to trade on the information without disclosure to others, or the information owner may be granted the right 
egalitarians, inside information could be treated as a "public resource," meaning that no person has the right to trade on inside information without prior public disclosure. This legal regime would forbid some or all insider trading by forcing disclosure of inside information to the marketplace prior to trading on it. In this Part, I argue that this policy alternative should be rejected, not only because it fails to accord sufficient concern to the need to grant incentives for the dissemination of information, but also because, despite its adherents' tendency to frame their argument in terms of fairness, this proposal also fails substantially to foster fairness goals.

Second, as proposed by informational-propertarians, the property right to inside information could belong to the issuer, as the creator of the inside information. I argue in Part $\mathrm{V}$ that this proposal should also be rejected, not only because it fails to accord sufficient concern to the public's right to informational access, but also because it is unlikely substantially to further market efficiency.

Finally, the law could adopt a middle ground in which a non-exclusive "property right" is granted to the possessors of inside information who are not actual or constructive insiders of the issuer. This approach, I argue in Part VI, strikes a more appropriate balance between incentives and accessa difficult balancing act, but one that is performed with some measure of success in connection with other types of intellectual property.

\section{A. Inside Information as a "Public Resource"}

As proposed by informational-egalitarians, valuable inside information could be treated as a public resource, meaning that no person would be legally entitled to trade on inside information without prior public disclosure. Although in its extreme form-strict parity of information-this regime would prohibit all insider trading, such an approach has apparently never been considered as a viable rule of modern law. ${ }^{102}$ The proposed legal re-

to prohibit others from using her information. See BAINBRIDGE, INSIDER TRADING, supra note 8, at 164. Most commentators in more traditional areas of property law, however, would take issue with the notion that permission to trade on information is a property right, and instead would refer to an entitlement of this sort as a privilege or liberty. See, e.g., Wesley Newcomb Hohfeld, Some Fundamental Legal Conceptions as Applied in Judicial Reasoning, 23 YALE L.J. 16, 30 (1913) (distinguishing "rights" from "liberties" or "privileges" and arguing that, in order to qualify as a right, someone else must have a corresponding duty, for example, to refrain from interfering with the right); Thomas Merrill, Property and the Right to Exclude, 77 NEB. L. REV. 730 (1998) (arguing that the right to exclude others is the "sinc qua non" of property). Economists, however, often refer to liberties or privileges as property rights, a practice that has been criticized as causing misunderstandings and a bias in economic analysis. Sec Daniel H. Cole \& Peter Z. Grossman, The Meaning of Property "Right": Law v. Economics? (Apr., 19, 2000) (unpublished manuscript, on file with author).

102 It is important to distinguish between a "parity of information" rule, which would prohibit any transaction between parties possessing unequal information, and an "equality of access" rulc, which would prohibit transactions in which one trading partner had information that the other did not have, and could not acquire, regardless of the amount of effort expended. Justice Blackmun explained the distinction well in Chiarella: "[T]here is a significant conceptual distinction between parity of information and 
gimes that treat information as a public resource thus forbid some, but not all, insider trading and include proposals, such as the classical, fraud-onthe-market, and equality of access theories of insider trading liability, which focus on the informed trader's duties to her trading partners. ${ }^{103}$

Those who would limit insider trading most often justify their position in terms of fairness. ${ }^{104}$ One criticism that has been leveled at such commentators is that they fail to define "faimess" in any meaningful way. ${ }^{105}$ It is possible, however, to ascertain at least two common conceptions of the unfairness caused by insider trading. Insider trading is typically perceived as unfair either because it causes some injury to specific traders or potential traders, or because it causes investors as a whole to lose confidence in the securities markets.

1. Investor Harm. The argument that insider trading causes some identifiable harm to specific traders has been disputed at length, with no persuasive story of the injury caused by insider trading yet to emerge. ${ }^{105}$ Perhaps the most plausible stories of investor harm from insider trading in-

parity of access to material information. The latter gives free rein to certain kinds of înformational advantages that the former might foreclose, such as those that result from differences in diligence or acumen." Chiarella v. United States, 445 U.S. 222, 252 n.2 (Blackmun, J., dissenting). Because a truly" level playing field would likely result in fewer market exchanges, a strict parity of information rule was apparently never seriously considered as a rule of modem law. Lawson, supra note 8, at $736-37$ ("Anglo-American contract law has never forbidden all trading in the absence of full diselosure, and, to paraphrase Professor Manne, I know of no modem commentator who has suggested that it should.").

103 Because the fraud-on-the-source version of the misappropriation theory focuses on the trader's duties to the information source, rather than her duties to other marketplace traders, the fraud-on-thesource version of the misappropriation theory more closely resembles a regime that treats inside information as the issuer's property, as opposed to public property. Sce Part $V$ infra (discussing legal regimes, including the fraud-on-the-source version of the misappropriation theory, that treat inside information as the issuer's property); see also infra note 115 (defining and contrasting the froud-on-themarket and fraud-on-the-source versions of the misappropriation theory).

104 See Jonathan R. Macey, Insider Trading: EConomics, Polmits and Policy 3 (1991); Bainbridge, supra note 4, at 55 ("[T]he most common argument against insider trading has been that it is unfair."'); Brudney, supra note 5, at 354-55; Levmore, supra note 23, at 118.

The insider trading prohibition has also been justified as preventing harm to the issuer and its shareholders and as promoting market efficiency by reducing the incentives for corporate management to delay disclosure of relevant information. See infra note 237 (discussing these arguments in greater detail).

${ }^{105}$ See Easterbrook, supra note 13, at 324 ("I suspect that few people who invoke arguments based on faimess have in mind any particular content for the term."); Levmore, supra note 23, at 119-20 (arguing that proponents of a "fair" insider trading rule have failed to define the term, and proposing a more definitive standard); Jonathan R. Macey, Elhics, Economics, and Insider Trading: Ayn Rand Mfeots the Theory of the Firm, 11 HaRv. J.L. \& PUB. POL'Y 785, 787 (1988) ("The current scholarship that decries insider trading as 'unfair' completely lacks reasoned argument. Often those who brand insider trading as unfair do not even attempt to explain what insider trading is, much less why it is unfair.").

106 This debate is far too lengthy to include here. Good discussions, however, are available in WILlLAM K.S. WANG \& MARC I. STEINBERG, INSIDER TRADING 13-117 (1996) and BAINBRIDgE, supra note 8 , at 149-64. 
volve distinctions between "time-function" and "price-function" traders and the increased bid-ask spreads that may result from insider trading. ${ }^{107}$

Despite the best efforts of scholars to prove otherwise, it has long been recognized that many investors are unaffected, or even benefited, by insider trading. It is true that, assuming insider trading alters security prices, some investors will sell at a lower price than they might have attained absent insider trading and some investors will purchase at a higher price than they might have absent insider trading, meaning that some investors are made worse off by the presence of insider trading. However, because someone, often an outsider with no access to material nonpublic information, is on the other side of such transactions, a corresponding number of investors will be able to sell at a higher price and buy at a lower price than they might have absent insider trading. Furthermore, these prices are closer to the price that would actually prevail in the marketplace if everyone had access to the nonpublic information available to insiders.

To illustrate, assume that insiders are aware of negative information regarding Alpha Corporation that, if disclosed, would cause the current per share market price of Alpha stock to drop from $\$ 25$ per share to $\$ 20$ per share. Prior to public release of the information, Alpha insiders sell Alpha stock on the basis of this negative information, reducing Alpha's price to $\$ 23$ per share. Some outsiders will undoubtedly sell at \$23 and could thus legitimately claim to be $\$ 2$ per share poorer than they would have been absent insider trading. A corresponding number of investors, however, will purchase at the more "correct" price of $\$ 23$ per share, making them better off than they would have been in the absence of insider trading. Although the $\$ 23$ per share price is higher than the $\$ 20$ per share price that would have prevailed if the insiders had been forced to reveal their secret information prior to trading, this harm is attributable to the lack of a general duty to disclose material nonpublic information under the federal securities laws and not to insider trading.

For time-function traders who are not induced to purchase or sell by stock price changes caused by insider trading, the fact that an insider was on the other side of the transaction is completely fortuitous. Time-function traders who transact with insiders on an anonymous exchange where the identity of buyers and sellers are unknown are no worse off than are those investors who transact with uninformed but lucky traders. Because they would have purchased or sold anyway, the only harm to time-function traders from insider trading results from share price alterations caused by in-

107 "Time-function" traders are those traders whose investment decisions are not dependent on changes in security prices, meaning that they are not induced by insider trading to purchase or sell. The investment decisions of "price-function" traders, by contrast, are induced by insider trading. See, e.g., Jonathan R. Macey, Securities Trading, A Contractual Perspective, 50 CASE W. RES. L. REV. 269, 273-74 (1999). 
sider trading activity and, as demonstrated, time-function traders as a group are not harmed by this price change.

Price-function traders present a more credible picture of investor harm. Price-function traders are investors-typically exchange specialists, market makers, portfolio managers, and other professional investors-who are induced to engage in or forgo trading activity by changes in security prices. ${ }^{103}$ Because price-function traders have views regarding the appropriate market price of a security based on their analysis of expected future cash flows, insider trading that alters stock price is likely to cause price-function traders to believe that the stock is currently over- or undervalued by the market and thus to engage in trades that they otherwise would have skipped or to forgo trades in which they otherwise would have engaged. Accordingly, insider traders as a class reap some portion of the profits that otherwise would accrue to uninformed outsiders upon the release of new information affecting stock price. ${ }^{109}$ This alone, however, is not sufficient evidence that insider trading is unfair. Stock market participants may suffer these same harms when forced to compete with investors whose informational advantages come not from access to inside information, but from superior research or analytical skills. In other words, the mere fact that someone is made worse off by insider trading is insufficient to support arguments that insider trading is unfair, immoral, or should be prohibited.

The far more serious concern regarding the harm suffered by pricefunction traders due to insider trading is the likelihood that market professionals do not absorb these losses themselves, but instead pass those costs on to public investors by altering their prices to reflect the risk of insider trading borne by market professionals, leading to increased bid-ask spreads and a potentially less liquid securities market. ${ }^{110}$ While the available empirical evidence regarding the impact of lax insider trading laws and enforcement policies on market liquidity is limited and mixed, ${ }^{\prime \prime}$ at least some

108 Id. at 274.

109 William K.S. Wang, Stock Market Insider Trading: Victims, Viololors and Remedics-Including an Analogy to Fraud in the Sale of a Used Car with a Generic Defect, 45 VILL. L. REV. 27,29 (2000) (discussing the "law of conservation of securities").

${ }^{110}$ See generally Georgakopoulos, supra note 4.

111 These studies are not dispositive of the thesis proposed in this Article: to prohibit insider trading by classical and temporary insiders and to leave trading by outsiders to regulation by private contract. Studies analyzing the impact of insider trading laws on market liquidity necessarily make no distinetion batween insider and outsider trading on the basis of material nonpublic information. Presumably, the decreased liquidity observed in those studies would be less severe in a regime where insiders, but not outsiders, were prohibited from exploiting their informational advantages. Indeed, most such studies employ the United States as an example of a regime with strong insider trading enforcement and high market liquidity. In fact, empirical evidence indicates that, although U.S. regulators have experienced greal suceess in deterring illegal insider trading by classical and temporary insiders, U.S. regulatory efiorts have been langely: ineffective in deterring illegal outsider trading. Nasser Arshadi, Insider Trading Liabiliny and Enforcement Strategy, 27 FiN. MGMT. 70, 70 (1998) (finding that insider trading regulation in the United States 
studies indicate that markets characterized by weaker insider trading regimes are less liquid than those markets in which prohibitions against insider trading are stringently enforced. ${ }^{112}$ These costs of insider trading must be balanced against any benefits provided by insider trading, such as increased market efficiency, and against the costs of insider trading regulation, which are substantial. Accordingly, the purpose of this analysis is not to suggest that there are no possible circumstances under which insider trading should be limited, but rather to suggest that the reasons for such limitation should not turn on amorphous and unsubstantiated notions of fairness. Instead, regulators should be forced to identify legitimate reasons for laws limiting insider trading and to analyze the benefits and costs of such rulesan exercise that has yet to be seriously undertaken.

2. The Integrity of Securities Markets. Perhaps because of the difficultly in identifying a clear victim of insider trading, insider trading regulation is more commonly justified as supporting some type of market integrity. In other words, if investors believe that the stock market is systematically unfair and accords advantages to insiders and others with superior access to material nonpublic information, then investors may exit the market, to the detriment of the marketplace and society generally. ${ }^{1 / 3}$

If investors' faith in the securities markets would be undermined by rampant insider trading, then the classical theory alone is inadequate to ensure investor confidence in the public markets. ${ }^{14}$ Investors are not so naive as to

has been reasonably effective at deterring trades by "registered and temporary insiders," but has failed to deter illegal insider trading by corporate outsiders).

112 Laura N. Beny, A Comparative Empirical Investigation of Agency and Market Theories of Insider Trading (1999) (unpublished manuscript, on file with author); Utpal Bhattacharya \& Hazcm Daouk, The World Price of Insider Trading (finding a roughly five percent reduction in the cost of capital in countries that enforce insider trading restrictions) (2000) (unpublished manuscript, on file with author).

113 See, e.g., Budney, supra note 5, at 356; Arthur Levitt, A Question of Integrity: Promoting Investor Confidence by Fighting Insider Trading, INSIGHTS, Apr. 1998, at 17 ("Trading on inside information . . . damages the entire structure of our markets, because it deeply shakes this vital investor confidence.").

The view that insider trading undermines investor confidence in the markets has been widely debated. For example, Professor Stephen Bainbridge has argued that, because there is no evidence that investors are actually harmed by insider trading, there is little cause to belicve that insider trading would undermine investor confidence. Stephen M. Bainbridge, Incorporating State Law Fiduciary Duties into the Federal Insider Trading Prohibition, 52 WASH. \& LEE L. REv. 1189, 1241-42 (1995). He further argues that the robust U.S. stock market performance after the highly publicized insider trading scandals of the 1980s undercuts the market integrity argument. Stephen M. Bainbridge, Insider Trading, in TuE ENCYCLOPEDIA OF LAW \& ECONOMICS 13 (1998), available at http://allserv.rug.ac.be/ gdegecst 5650art.htm. Furthermore, Professor Jonathan Macey argues that the experience of countries such as Japan, India, and Hong Kong, each of whom have lax insider trading prohibitions and enforcement mechanisms but vigorous securities markets, undermines the argument that insider trading may cause a loss of investor confidence in the public markets. See MACEY, supra note 104, at 44.

114 The Supreme Court has defined the classical theory as follows:

Under the "traditional" or "classical theory" of insider trading liability, \$10(b) and Rule 10b-5 are violated when a corporate insider trades in the securities of his corporation on the basis of material, 
believe that only the issuer's employees have systematic informational advantages. While the fraud-on-the-market theory brings more transactions within the insider trading prohibition, like all misappropriation theories, its loopholes and shortcomings make it a particularly shaky underpinning for furthering any notion of preserving investor confidence in the securities markets. ${ }^{115}$

By focusing on disclosure to investors rather than on disclosure to the issuer, the fraud-on-the-market theory eliminates some of the more vexing problems posed by the Supreme Court's fraud-on-the-source theory. ${ }^{116}$ In the end, however, the fraud-on-the-market theory, like other informationalegalitarian theories, fails to answer the most basic question necessary to an informed insider trading regulatory policy: why are some types of informational advantages prohibited while other types are not?

Perhaps because of these limitations of the classical and misappropriation theories, scholars have long been attracted to the notion that insider trading law should explicitly seek to place market participants on a more equal informational footing regardless of a fiduciary breach. In fact, although the Supreme Court explicitly rejected the equality of access approach to insider trading liability under Rule 10b-5 in Chiarella, it has been argued that the misappropriation theory, explicitly adopted by the Supreme Court in O'Hagan, is a mere pretext by the Commission, with the concurrence of the

nonpublic information. Trading on such information qualifies as a "deceptive device" under $\$ 10(b)$, we have affirmed, because " 3 relationship of trust and confidence [exists] between the shareholders of a corporation and those insiders who have obtained confidential information by reason of their position with that corporstion."

United States v. O'Hagan, 521 U.S. 642, 651-52 (1997) (quoting Chiarella v. United States, 445 U.S. 222, $228(1980)$ ).

115 Both the fraud-on-the-source version and the fraud-on-the-market version of the misappropriation theory arose from the Supreme Court's 1980 decision in Chiarella v. United States, 445 U.S. 222 (1980). The fraud-on-the-source theory, which was argued by the government as a basis for liability in Chiarella and discussed with some approval in Justice Stevens's concurring opinion, holds that the misappropriation of inside information from one to whom a duty of trust and confidence is owed gives rise to a duty of disclosure to that person. See 445 U.S. at 238 (Stevens, J., concurring). The froud-on-themarket theory, by contrast, was favored by Chief Justice Warren Bunger in his dissenting opinion, and holds that the misappropriation of confidential information gives rise to a duty of diselosure to oiner marketplace actors. Id. at 240-41 (Burger, C.J., dissenting).

116 The most skillful exposition of the fraud-on-the-market theory is contained in Nagy, supra note 5. I, and others, have criticized the misappropriation theory and, in particular, the fraud-on-the-souree version of that theory, at length elsewhere and those criticisms are not repeated here. Ske, eg., Richard W. Painter, Kimberly D. Krawiec \& Cynthia A. Williams, Don't Ask, Just Tell: Insider Trading Affer United States v. O'Hagan, 84 VA. L. REV. 153 (1998) (criticizing O'Hagan and the misappropriation theory); see also Bainbridge, supra note 5; Nagy, supra note 5; Ribstein, supra note 5. Instead, I emphasize simply that $O$ 'Hagan not only raised more questions than it answered, but by conditioning insider trading liability on the breach of a fiduciary duty owed to a principal, regardless of whether the principal has an interest in the securities being traded or is even a market participant at all, the misappropriation theory divorees insider trading liability from any conceivable source of investor protection. 
federal courts, to evade Chiarella's limitations. ${ }^{17}$ Accordingly, O'Hagan arguably revived at least some portion of the equality of access theory. ${ }^{118}$

The equality of access theory, at first glance, appears to have the advantage of consistency by avoiding the misappropriation and classical theories' emphasis on factors unrelated to fairness to other securities traders or marketplace integrity. Yet, this apparent consistency is only superficial. First, it is unclear why equality of any sort is suddenly demanded in securities transactions when many levels of inequality, including inequality in access to information, is considered normal business practice in many other contexts. ${ }^{119}$ Even federal courts imposing insider trading liability seem to recognize the inherent contradiction of such a result. As the Second Circuit stated in United States v. Carpenter: "There are disparities in knowledge and the availability thereof at many levels of market functioning that the law does not presume to address."

Furthermore, even if the inquiry is confined to securities markets, a deeper look reveals that securities market participants do not have equal access to information, or even equal access to the marketplace. ${ }^{121}$ This dispar-

117 Charles C. Cox \& Kevin S. Fogarty, Bases of Insider Trading Law, 49 OH1O ST. L.J. 353, 366 (1988) ("IT]he whole [misappropriation] theory is merely a pretext for enforcing equal opportunity in information.").

118 Bainbridge, supra note 5, at 1648 (stating that the majority opinion in O'Hagan constitutes an "arguable revival of the long-discredited equal access theory of liability."); Elliot J. Weiss, United States v. O'Hagan: Pragmatism Returns to the Law of Insider Trading, 23 J. CORP. L. 395 (1998); see also $O^{\prime}$ Hagan, 521 U.S. at 659 (arguing that misappropriators enjoy an informational advantage "that cannot be overcome with research or skill').

119 A commonly cited example of this phenomenon is the land sale transaction at issue in S.E.C. $v$. Texas Gulf Sulphur Co. 401 F.2d 833 (2d Cir. 1968); see also Paula J. Dalley, From Horse Trading to Insider Trading: The Historical Antecedents of the Insider Trading Debate, 39 WM. \& MARY L. REV. 1289, 1290 (1998) (citing Texas Gulf Sulphur as an example of the general presumption of caveat emp. tor in arms-length business transactions); Fisch, supra note 7, at 251 n.189 (same). In Texas Gulf Sulphur, Texas Gulf wanted to buy a tract of land that it knew contained valuable mineral deposits, although the owner of the land was unaware of that fact. The Second Circuit found Texas Gulf liable under Rule $10 \mathrm{~b}-5$ for failing to disclose the valuable ore deposit to the securities traders who had sold their stock to the company. The Ontario High Court of Justice, however, nuled that Texas Gulf was under no obligation to disclose this same information to the owner of the property before purchasing it at a price far below its true value. Leitch Gold Mines, Ltd. v. Texas Gulf Sulphur Co., 1 O.R. 469, 492-93 (1969).

120791 F.2d 1024, 1031 (2d Cir. 1986), affd, 484 U.S. 19 (1987).

121 It has been frequently noted, for example, that the average investor is routinely excluded from the new issue market at the initial public offering price. Michael Siconolfi, The Spin Desk: Underwriters Set Aside IPO Stock for Officials of Potential Customers, WALL ST. J,, Nov, 12, 1997, at A1 [hereinafter Siconolf, Spin Desk] ("It is no news that underwriters make most of the shares in hot IPOs available not to the little-guy investor but to institutions, such as mutual-fund companies and pension funds, that provide a lot of trading commissions and other business."). This practice favors large investors by permitting them to earn huge profits by quickly selling IPO shares in the aftermarket, which often soars by as much as $50 \%$ on the first day of trading, due to high demand from investors who were unable to purchase in the initial IPO distribution. See id.; see also Michael Siconolfi, SEC Broadens 'Spinning' Probe to Corporations, WALL ST. J., Dec. 24, 1997, at C1 [hereinafter Siconolfi, Spinning Probe]. The practice, however, is not illegal. This is in contrast to the practice known as "spinning," the allocation of desirable IPO shares to the discretionary trading accounts of corporate executives and 
ity is particularly obvious if one recognizes that there is a distinction between formal equality of access and actual equality of access. For example, analysts and professional investors who have the time and resources to monitor the marketplace continuously have access to much information that, while "public" in theory, is simply not available on a timely basis to the average investor.

Such limited, though technically public, information goes beyond the ability of professional investors to monitor the ticker tape continuously and discover obscure public filings and news items. For example, some market professionals frequent the headquarters or other offices of corporations, hoping to discern relevant information. ${ }^{122}$ Arbitragers and other professional investors specializing in takeovers routinely monitor courtroom trials open to the public in an attempt to glean any potential information regarding the likelihood that a takeover may go forward or fall through due to a legal snag. ${ }^{123}$

Rather than being perceived as somehow unfair, however, such conduct is considered as "American as apple pie" and the profits made from trading on such information are considered the just reward for time-consuming research. ${ }^{124}$ The public acceptance of this type of conduct is evidenced by the controversy surrounding U.S. District Court Judge Stanley Sporkin's recent statements that such behavior, in his view, constitutes insider trading. ${ }^{125}$

In addition, professional investors and analysts have traditionally been given confidential information in meetings or interviews with the issuer's in-

venture capitalists, in the hopes that the executive will award future investment banking business to the underwriting firm. See Siconolfi, Spin Desk, supra, at Al. Spinning is of questionable legality. See Siconolfi, Spinning Probe, supra.

The standard defense of this inequality in the IPO market is that individuals profit from this practice by purchasing shares in mutual funds, which are the largest beneficiaries of current IPO share alloeation practices. See Randall Smith \& Suzanne McGee, Major Institutions, Led by Fidelin;, Get Most of Hot IPOs, Lists Show, WALL ST. J., Jan. 27, 2000, at Cl (noting that the IPO allocation of Fidelity Investments, a large mutual fund, is twice that of most other institutions). Given the poor performance of most mutual funds, however, this argument should be recognized for the author reasoning that it is, rather than as a legitimate defense of market inequality. Sce infra notes 144-55 and accompanying text (discussing author reasoning and the romanticization of analysts and other market professionals that leads to their preferential treatment under the securities laws).

${ }^{122}$ Steven Lipin, Judge Blasts M\&A Plajers' Zcal for Edge, WALL ST. J., Jan. 25, 1999, at C19. The public perception that this type of activity is unfair and illegal under current insider trading laws is demonstrated by the movie Wall Street. In one of the film's more memorable scenes, Charlie Sheen's character, Bud Fox, tails a known corporate raider and relates his movements to Gordon Gekko (played by Michael Douglas), who then trades on the information. The film's director (Oliver Stone) seems to believe that movie audiences will perceive Fox's and Gekko's conduct as both morally offensive and illegal under United States insider trading laws. I am grateful to Professor Jennifer O'Hare for this amusing illustration.

${ }^{123}$ Lipin, supra note 122.

124 See id. (quoting banker's and lawyer's statements that such behavior is not "unfair or inappropriate" and that arbitrage is a "research-driven business").

${ }^{125}$ Id. (quoting Judge Stanley Sporkin's statement that investors "know that insider trading is wrong and yet they condone the practice simply by calling it arbitrage"). 
siders. ${ }^{126}$ Such information is not available to other investors either in theory or in fact. While Commission Chairman Arthur Levitt has publicly argued against this practice, stating that it is unfair and undermines investor confidence in the securities markets, and the Commission has recently adopted new rules limiting the practice, until this year the Commission has been content to rely on self-restraint rather than legal rules to control such conduct. ${ }^{127}$

If insider trading is prohibited because of a belief that securities traders deserve some level of fairness or informational equality, then why are informational inequalities such as these not only tolerated, but applauded? I argue in the following subpart that the answer lies in the traditional public/private distinction that pervades much of mainstream political and legal discourse and, in particular, in author reasoning. ${ }^{128}$

\section{B. Deconstructing the Fairness Argument}

Insider trading law currently attempts to draw the line between legal and illegal informational advantages by reference to breach of a fiduciary duty. ${ }^{129}$ Because the gathering of information through a fiduciary breach is not considered socially productive behavior, there is no identifiable romantic author whose diligence and effort must be rewarded through permission to profit from such informational advantages. ${ }^{130}$ Information gained through a fiduciary breach, therefore, is considered part of the public sphere and, along with other public sphere privileges, such as access to the criminal justice system or the right to vote, must be shared equally among marketplace participants. This egalitarian goal is accomplished by forcing

126 Levitt, supra note 113, at 17; see also Susan Pulliam \& Gary McWilliams, Compaq Is Criticized for How It Disclosed PC Troubles, WALL ST. J., Mar. 2, 1999, at Cl (reporting that a Compaq Corporation official disclosed during a tour with several important investors that personal computer sales were below initial expectations. Compaq stock fell by $16 \%$ the following day as the news became more widely known).

127 Regulation FD, 17 C.F.R. § 243.100-.102 (2000); Levitt, supra note 113, at 17 (stating that the Commission "hope[s] that self-restraint will solve the problem-before we [the Commission] have to step in" and that "Legally, you can split hairs all you want. But ethically, it's very clear: If analysts or their firms are trading - knowing this information, and prior to public release-it's just as wrong as if corporate insiders did it."). It has been cogently argued that, despite the Commission's insistence that Regulation FD protects investors and promotes faimess in the securities markets, Regulation FD (and particularly its exemption for foreign issuers) cannot be supported on faimess grounds. Merritt B. Fox, Regulation FD and Foreign Issuers: The Strains of Globalization, 41 VA. J. INT'L L. (forthcoming 2001).

128 See supra subpart III.B (introducing the concept of author reasoning).

129 In the case of classical insider trading liability, the duty is owed by the insider to the corporation and its shareholders. See supra note 114 (discussing the classical theory of insider trading liability). In the case of liability under the misappropriation theory, the duty is owed to an employer, family member, partner, or some other person or entity to whom the trader stands in a relationship of trust and confidence. See supra note 115 (discussing the misappropriation theory).

130 See, e.g., Chiarella v. United States, 445 U.S. 222, 222 (1980) (Burger, C.J., dissenting) (stating that Chiarella's acquisition of tender offer information through breach of a fiduciary duty to his employer "quite clearly serves no useful function except [Chiarella's] enrichment at the expense of others."). 
those in possession of secret knowledge attained through a fiduciary breach to disclose that information prior to trading. ${ }^{131}$

By contrast, nonpublic information gained through means other than a fiduciary breach is considered socially useful research that must be rewarded by permitting the information possessor to profit from her superior trading knowledge. ${ }^{132}$ Such information, therefore, is subconsciously delegated to the private sphere where, along with other private sphere resources, such as wealth, experience, or education, equality is not expected. Consequently, those in possession of material nonpublic information attained through means other than a fiduciary breach are permitted to trade on that information without disclosure to their trading partners.

Once the superficial distinctions of public and private are deconstructed, however, the hollowness of current insider trading law becomes obvious. From the standpoint of investors, the role of a fiduciary breach in information acquisition is meaningless. If an investor feels that she has been defrauded in a securities transaction because her counterparty possessed secret information, it is doubtful that these feelings of being cheated are alleviated by reminding the investor that the information in question was obtained without any fiduciary breach. ${ }^{133}$ Similarly, defenders of the current system of insider trading regulation have failed to explain why trading on information overheard in conversations, ${ }^{134}$ gleaned from documents in a briefcase stolen from a stranger, ${ }^{135}$ entrusted to a hairdresser by one of

131 This is referred to as a "disclose or abstain" rule. Sce infra Part VI (discussing disclose or abstain rules).

132 Brudney, supra note 5, at 341 ("Exploration for relevant corporate and cconomic information is a service of value in the functioning of the market.").

133 The connection between the perceived harm to the investor and the breach of a fiduciary duty is particularly attenuated when, as in the misappropriation context, the source of the information to whom the duty is owed is not the issuer or its shareholders.

${ }^{134}$ See S.E.C. v. Switzer, 590 F. Supp. 756 (W.D. Okla. 1984) (finding that University of Oklahoma football coach Barry Switzer did not violate Rule $10 \mathrm{~b}-5$ by trading stocks based on information overheard at a track meet).

135 The United States conceded at oral argument that trading on information stolen from a person to whom the trader owed no pre-existing fiduciary duty would not constitute a violation of Rule 10b-5. See United States Supreme Court Official Transcript, United States v. O'Hagan, 521 U.S. 642 (1997), available at 1997 WL 182584 at *5 ("QUESTION: Well, Mr. Dreeben, then if someone stole the lawyer"s briefcase and discovered the information and traded on it, no violation? MR. DREEBEN: That's correct, Justice O'Connor."). Although the Court's opinion does not explicitly adopt this coneession, Justice Ginsburg's opinion seems to comport with the government's position. For example, she states that rule 10b-5 liability stems from the misappropriation of information entrusted to an agent by a principal. O'Hagan, 521 U.S. at 652 . The information in the Court's briefcase example clearly was not entrusted to the thief. Consequently, the hypothetical would not seem to implieate the misappropriation theory as outlined in $O^{\prime}$ Hagan. In addition, the Ginsburg opinion seems to contemplate a preexisting fiduciary relationship. For example, she states that "the deception essential to the misoppropriation theory involves feigning fidelity to the source of information." Id. at 655. It is difficult to imagine how one might "feign fidelity" to a complete stranger. 
her clients ${ }^{136}$ or to a husband by his wife ${ }^{137}$ are socially useful activities while trading on information gained in a tip from an insider, ${ }^{138}$ from information stolen from one's employer or father, ${ }_{140}^{139}$ or entrusted to a physician by his patient are not socially useful activities. ${ }^{140}$

In contrast to the current legal regime's focus on a fiduciary breach as the means to distinguish legal informational advantages from illegal ones, equality of access advocates maintain that informational advantages that cannot be lawfully eroded through the expenditure of sufficient time and effort should be prohibited. However, like defenders of the current legal regime, equality of access advocates also rely on author reasoning in arguing that insider trading regulation should promote socially useful research. ${ }^{147}$ Because informational advantages that cannot be lawfully eroded through the expenditure of sufficient time and effort, such as, for example, the informational advantages possessed by a corporate insider or misappropriator, are not considered socially useful research, there is no romantic author whose skill and effort must be rewarded with permission to profit from her inside information. ${ }^{142}$ Such information, therefore, is part of the public sphere and must be shared with other securities traders before the information possessor is permitted to exploit her informational advantage through securities trading. Consequently, trading based on informational advantages that cannot be lawfully eroded would be prohibited under an equality of access approach to insider trading regulation. ${ }^{143}$

Equality of access advocates contend with the informational advantages enjoyed by market professionals by arguing that, although every investor does not have the opportunity to become a corporate insider or misappropriator or a tippee of an insider or misappropriator, every investor

136 John R. Beeson, Comment, Rounding the Peg to Fit the Hole: A Proposed Regulatory Reform of the Misappropriation Theory, 144 U. PA. L. REV. 1077, 1137 (1996). The hairdresser's trades should not run afoul of Rule 10b-5 because the relationship between client and hairdresser does not give rise to a fiduciary duty under state law.

${ }^{137}$ See United States v. Chestman, 947 F.2d 551 (2d Cir. 1991) (en banc) (finding that a husband did not violate Rule $10 \mathrm{~b}-5$ by trading on information entrusted to him by his wife).

${ }^{138}$ See infra note 26 (explaining tippee liability under Dirks).

139 See United States v. O'Hagan, 521 U.S. 642 (1997) (finding James Herman O'Hagan guilty of violating Rule $10 \mathrm{~b}-5$ by trading on information misappropriated from his employer, a law firm representing the acquirer in a takeover bid); United States v. Reed, 601 F. Supp. 685 (S.D.N.Y. 1985), rev'd. 773 F.2d 477 ( $2 \mathrm{~d}$ Cir. 1985) (finding that a son violated Rule 10b-5 by trading on information entrusted to him by his father).

140 United States v. Willis, 778 F. Supp. 205 (S.D.N.Y. 1991) (denying a psychiatrist's motion to dismiss allegations of insider trading based on information gained from one of his patients during a therapy session).

141 Brudney, supra note 5, at 360-63; see also O'Hagan, 521 U.S. at $658-59$ (stating that "[a]n investor's informational disadvantage vis-à-vis a misappropriator with material, nonpublic information stems from contrivance, not luck; it is a disadvantage that cannot be overcome with research or skill").

142 Brudney, supra note 5, at 354-55.

143 Id. at 376. 
could purchase the services of an investment analyst. ${ }^{144}$ Investment analysts, market makers, exchange members, and others who are assumed to provide socially useful research are thus romantic authors whose beneficial behavior must be rewarded though permission to profit from their informational advantages. Information attained through the research of such parties, therefore, is considered part of the private sphere and can be freely exploited in the pursuit of trading profits. ${ }^{145}$

Such arguments by equality of access proponents employ semantics to mask a profound inequality in the securities markets that is inconsistent with any notion of faimess. One point of symmetry between even traditional law and economics scholars and postmodernist scholars is the ability to see through such errors in main-stream legal discourse. Professor (later Judge) Frank Easterbrook, for example, noted long ago that inequalities in access to information will mirror the inequalities in wealth, intelligence, and access to human capital in society at large, as information acquisition is merely a function of these other factors. ${ }^{146}$ Equality of access advocates, limited by subconscious adherence to public/private distinctions, apparently believe that formal legal mandates prohibiting informational inequalities can overcome these underlying limitations. As discussed in Part III, however, liberating individuals from formal, public inequalities does not free them from private inequalities. ${ }^{147}$ Consequently, societal differences in access to information cannot be eliminated unless we are prepared to eliminate societal inequalities in access to wealth, education, employment opportunities, and human capital, a step that few, if any, informational egalitarians would likely support. ${ }^{188}$

144 Id. at 361-63. Indeed, it has been argued that the preferential treatment extended to analysts and professional investors under the securities laws may represent a much greater unfaimess to individual investors than if insider trading were actually permitted. Commentators have noted that it is primarily analysts and professional traders that benefit from insider treding regulation. MACEY, supra note 104, at 17-20 (discussing public choice theory as applied to insider trading); Bainbridge, supra note 5, at 17 (arguing that insider trading regulation has been "supported and driven" by mariet professionals who are insulated from liability under the current regime); Haddock \& Macey, Coasian drodel, supra note 9, at 1457-58 (discussing public choice theory as applied to insider trading). It has also been argued that the advantages accorded to analysts and other market professionals may lead to excessive research that merely reallocates profits without enhancing efliciency. Eugene F. Fama \& Arthur B. Laffer, Information and Capital Markets, 44 J. BuS. L. 289 (1971) (discussing private ineentives to engage în an overproduction of information); Jack Hirshleifer, The Private and Social Value of Information and the Reward to Inventive Activity, 61 AM. ECON. REV. 561, 572 (1971) (same).

145 See Brudney, supra note 5, at 360-63; Donald C. Langevoort, Investment Analysts and the Law. of Insider Trading, 76 VA. L. REV. 1023, 1032 (1990).

146 Easterbrook, supra note 13, at 330 ("People do not have or lack 'access' in some absolute sense. There are, instead, different costs of obtaining information .... The different costs of access are simply a function of the division of labor .... But unless there is something unethieal about the division of labor, the difference is not unfair.").

147 See supra subpart III.A (discussing the public'private distinction).

148 See e.g., Paul G. Mahoney, Technology. Property Rights in Information, and Securities Rcgulation, 75 WASH. U. L.Q. 815,816 (arguing that "technology is helping to expose the limits of the regula- 
When analyzed in this manner, the equality of access theory's labeling as "publicly available" all information acquired through advantages that can be lawfully eroded appears not only unworkable, but nonsensical. To illustrate, Professor Victor Brudney, referring to investment analysts and brokers, argues that "information is not lawfully unavailable merely because of the unwillingness (except for a fee) of the person who has incurred the cost of collecting and assembling items of information that are otherwise available to a diligent investigator to share them with those with whom he trades." 149 This same argument holds true with respect to all types of information, however. Nonpublic corporate information, for example, is only legally unavailable to outsiders if they choose not to purchase the information from the corporation or become an insider of the corporation. ${ }^{150}$

While neither of these options will appear especially attractive or feasible to most investors, the same is true of the barriers to acquisition of much "publicly available" information. ${ }^{151}$ Taken to its logical extreme, the equality of access theory would imply that all information is theoretically publicly available. After all, there are no legal barriers that prevent an investor from expending all of her time and resources to become a corporate officer or director - or the psychiatrist, spouse, priest, or other confidante of one-or to purchase information directly or indirectly from the corporation.

Other commentators have persuasively countered the equality of access contention that information obtained by analysts and other market professionals is publicly available by noting that investment analysts do not distribute important information equally to their clients. ${ }^{152}$ Instead, valuable information is often sold to the highest bidder or reserved only for favored clients. The information available to remaining clients will often appear in the form of a newsletter in which the most valuable information is either

tory system's ability to eliminate informational asymmetries in securities markets"); id. at 837 (noting that the greater wealth of brokerage firms and banks gives them access to more technology and, consequently, more information, than most investors despite the Commission's mandatory disclosure rules).

149 Brudney, supra note 5, at 361.

150 Lawson, supra note 8, at 757; Frank Easterbrook \& Daniel Fischel, Trading on Inside Information, in THE ECONOMIC STRUCTURE OF THE CORPORATE LAW 254 (1991) ("If one who is an 'outsider' today could have become a manager by devoting the same time and skill as today's 'insider' did, is access to information outside of the tender offer context equal or unequal? There is no principled answer to such questions."). The selling of such corporate information outside of the tender offer context is presumably illegal only if sold in breach of a fiduciary duty. See Dirks v. S.E.C., 463 U.S. 646, 661 (1983) (holding that tipping violates Rule 10b-5 only if done in breach of a fiduciary duty of which the tippec is or should be aware). If the information is sold for a fair price and the funds are deposited in the corporate treasury, there is no reason to believe that such sales would be considered a fiduciary breach.

151 Lawson, supra note 8, at 757.

152 Fisch, supra note 7, at 251 n.190; Langevoort, supra note 145, at 1039; Pulliam \& McWilliams, supra note 126 (stating that "the little guy can forget about getting a call from a broker" regarding im. portant nonpublic corporate information). 
omitted or has already been exploited for any profit potential by betterinformed traders. ${ }^{153}$

The equality of access argument that insider trading law seeks to further socially useful research while prohibiting the exploitation of informational advantages that do not contribute to the social welfare is similarly difficult to defend. First, the social utility of many legally permitted informational advantages is not obvious, particularly considering the questionable relevance and reliability of some of this information. ${ }^{154}$ Furthermore, many informational advantages that are not legally permitted to be exploited through insider trading contribute significantly to the social welfare. For example, unless one accepts the argument that becoming a corporate officer or director or accumulating sufficient wealth to purchase nonpublic corporate information requires no talent or effort and, therefore, is not a socially useful activity deserving of reward, it is difficult to retrieve any useful guidance from the equality of access theory as to where the line separating legal from illegal informational advantages should be drawn. ${ }^{155}$

Finally, as previously stated, the origin of information is likely to be irrelevant to investors, whose primary concern is merely that other marketplace traders have information unavailable to them. An investor's sense of the unfairness of securities markets is thus unlikely to be assuaged by reassurances that the material information possessed by her trading partner and not by her is technically public and that if she cares to quit her job and instead spend all day monitoring courtroom trials, searching for obscure public reports or loitering at corporate offices she is likely to discover this same information. Rather, investors are likely to feel that such transactions are unfair regardless of whether the unshared information was acquired through breach of a fiduciary duty, through theft, from a disclosure made to analysts in a closed session, or from information that, while public in theory, is simply beyond the reach of the average investor.

\footnotetext{
153 Fisch, supra note 7, at 251 n.190; Langevoort, supra note 145, at 1039.

154 Using the example of arbitragers' courtroom "rescarch" discussed carlier, only the judge's final ruling is actually relevant to the stock's intrinsic value. Sce supra notes $123-25$ and accompanying text. Arbitragers monitor the entire proceeding, however, and place bets on the future outcome of the trial based on the judge's body language, extraneous courtroom comments and rulings on interim motions. Lipin, supra note 122. Arguably, this type of research prior to a final decision merely adds unnecessary volatility to the stock price. This is evidenced by the stock price fluctuations of Bergen Brunswig Corp. and AmeriSource Health Corp., two potential target corporations in deals the Federal Trude Commission attempted to prevent. Id. After Federal District Court Judge Stanley Sporkin made courtroom comments perceived by arbitragers as positive, the stock prices of both companies soared on speculative trading. Both stocks plunged, however, after Judge Sporkin ultimately sided with the FTC and ruled against the combinations. Id. Fuel was added to the controversy surrounding Judge Sporkin's public statements that arbitrage based on information of this type bordered on insider trading when he commented that he had "fixed" the arbitragers, leading many wall strect observers to believe that Judge Sporkin had intentionally misled traders in an attempt to discourage behavior that he viewed as unfair to other investors. Id.

155 Lawson, supra note 8, at 757.
} 


\section{INFORMATIONAL PROPERTARIANISM-THE EFFICIENCY ARGUMENT}

Most commentators advocating an insider trading rule that furthers informational efficiency rely on the argument that insider trading regulation should be approached as a matter of protecting the issuer's property right in valuable information. This, it is argued, will encourage issuers to produce the socially optimal amount of information by allowing information creators to profit from that activity. ${ }^{156}$

Current insider trading law in many ways closely resembles just such a regime. The fraud-on-the-source version of the misappropriation theory, adopted by the Supreme Court in United States v. O'Hagan, goes a long way toward regulating the "theft" of valuable inside information. 157

The idea that insider trading regulation should seek to protect issuers' rights in valuable information has been vigorously criticized by informational-egalitarians, primarily through arguments that the purpose of the federal securities laws is to foster fairness in securities markets and to protect investors, not to protect issuers' intellectual property. ${ }^{158}$ This Article takes a different tack by arguing that informational-propertarians, like their egalitarian counterparts, also rely on subconscious notions of a sharp division between the public and private spheres and, in particular, on the romantic author ideal.

Whereas informational-egalitarians focus on information's public good quality and often misperceive information as an infinite public sphere resource that should be shared as widely and as equally as possible, informational-propertarians err to the other extreme. Focusing on information's

156 See, e.g., United States v. Chestman, 947 F.2d 551, 576-77 (2d Cir. 1991) (en banc) (Winter, J., dissenting); Bainbridge, supra note 5, at 1590; Macey, From Fairness to Contract, supra note 9, at 62.

157 See A.C. Pritchard, United States v. O'Hagan: Agency Law and Justice Powell's Legacy for the Law of Insider Trading, 78 B.U. L. REV. 13, 48 (1998) (arguing that the misappropriation theory protects property rights in valuable information and also protects investors and stock market integrity). In other respects, however, current law does not resemble a system of private property rights in issuers. See, e.g., Fisch, supra note 7, at $251 \mathrm{n} .196$ (noting that if the prospective bidder in a tender offer tips a friend about the upcoming tender offer and advises the friend to purchase target shares, the friend will be guilty of insider trading under Rule $14 \mathrm{e}-3$ and the rule, therefore, is inconsistent with a property-rights approach to insider trading liability). Similarly, the classical theory of insider trading liability, unlike an intellectual property rights system, does not permit the issuer or its shareholders to opt out of the insider trading regulation scheme of Rule $10 \mathrm{~b}-5$, a point forcefully criticized by informational-propertarians. But see Prakash, supra note 7, at 1493 n.6, 1495 (arguing that so long as a classical insider discloses her intent to trade based on inside information, neither the issuer's permission nor disclosure of the inside information is required).

158 Fisch, supra note 7, at 225 (noting that, although the property rights approach focuses on harm to the source of information or to the issuer, consistent with the classical and misappropriation theorics, this does not seem consistent with the real reason we prohibit insider trading, which is a perceived unfaimess to investors); Karmel, supra note 37, at 113 ("The easiest criticism of the property rights theory is that when Congress passed and subsequently amended the Exchange Act, it was concerned about fairness and the protection of investors, not the protection of property rights in information held by issuers and traders."). 
collective good quality, they misperceive information as a private sphere commodity and advocate endowing issuers with private property rights in inside information in order to incentivize production. While informationalegalitarians striving for some rational justification for the differential treatment of inside information under the federal securities laws romanticize analysts, specialists, and other market professionals, informationalpropertarians turn the issuer itself into a romantic author deserving of private property rights in information. Misappropriators and insiders who trade on inside information without the issuer's consent, on the other hand, are deemed to perform no valuable function and are not rewarded with a property right in the information they possess.

The extent of informational-propertarians' subconscious reliance on public/private distinctions is evidenced by the fact that, despite their tendency to focus on efficiency as an appropriate goal of insider trading regulation, it is doubtful that the grant of intellectual property rights in issuers will further that goal. This argument rests on the following three separate bases: (1) the skepticism of many economists and legal scholars toward the view that the grant of private property rights in information producers will lead to the optimal level of information production and dissemination; (2) the low probability that issuers would discontinue or reduce information production in the absence of a property right, given the possibility of multiple uses for the same information; and (3) the general reluctance that the American legal system has shown toward recognizing property rights in raw information, in the belief that such an endowment would restrict information distribution, leading not only to less fairness, but to less efficiency as well.

\section{A. Skepticism Toward Intellectual Property As a Means 10 Optimal Information Production and Dissemination}

Subsections II.A.2.a and $b$ demonstrated the traditional economic theory that collective goods are often overconsumed or underproduced and that common ownership generally results in an inefficient use of resources. Subsection II.A.2.c then presented the neoclassical economic resolution to the collective good dilemma: the creation of a system of private property rights in limited resources. This subpart first considers challenges to the neoclassical economic argument that private ownership will resolve the collective good dilemma and that use and production are necessarily maximized in a system of private property rights. This subpart then explores arguments that, even if other collective goods are more efficiently produced and consumed under a system that rewards producers with private property rights, information's unique economic qualities necessitate a more careful weighing of incentives with access.

It is important to recognize as an initial matter that there is no single "economic theory," a point often overlooked by critics of law and economics. It is true, however, that a particular strain of economic theory, neoclas- 
sical economics, has dominated law and economic analysis in the United States, due primarily to the influence of "Chicago School" law and economics, which tends to apply neoclassical economic principles to the analysis of laws and legal institutions. ${ }^{159}$

Property rights are an essential element of neoclassical economics. ${ }^{160}$ According to neoclassical economic theory, the right of exclusion granted to owners of private property permits the internalization of benefits and forces the internalization of costs, encouraging the efficient consumption and production of resources. ${ }^{161}$ Just as importantly, the transfer of those rights permits market forces to allocate resources to their highest valued uses, resulting in allocative efficiency and enhanced social welfare.

Neoclassical economics thus proposes a universal system of private property rights as a means to avoid the potential inefficiency of common ownership-in other words, in the neoclassical view, all valuable goods should be privately owned. ${ }^{162}$ In such a system, individuals are granted the right to use certain property and exclude others from it, meaning that such

159 See MERCURO \& MEDEMA, supra note 67, at ix (1997) (stating that law and economics reflects several traditions, including public choice theory, institutional economics, neo-institutional cconomics, the New Haven School, modern civic republicanism, and critical legal studies); Netanel, stupra note 14, at 311 (discussing the influence of Chicago School law and economics and its reliance on ncoclassical economic principles); Martha C. Nussbaum, Flawed Foundations: The Philosophical Critique of (A Particular Type of) Economics, 64 U. CHI. L. REv. 1197, 1197 (1997) (arguing that Law and Economics has for the most part been built on the conceptual foundations of neoclassical economics and has largely ignored other schools of economic thought).

"Chicago school" law and economics is a phrase (sometimes intended pejoratively) used to describe a particular means of analyzing the law and the legal system by reference to certain economic hypotheses. See Edmund W. Kitch, Chicago School of Law and Economics, in 1 THE NEW PALGRAVE DictionaRY OF ECONOMICS \& THE LAW 227 (Peter Newman ed., 1998). Some of the more important of those hypotheses are as follows: that human beings act as rational utility maximizers, that marketdetermined outcomes advance social welfare and that government intervention in the markctplace is normally unlikely to enhance social welfare.

160 Many of the theories attributed in this article to neoclassical economics may hold true for other economic movements or schools as well, especially new institutional economics.

161 BLACKSTONE, supra note 24, at 7 ("[W]ho would be at pains of tilling [the earth], if another might watch an opportunity to seize upon and enjoy the product of his industry, art, and labour? Had not therefore a separate property in land, as well as moveables, been vested in some individuals, the world must have continued a forest."); POSNER, supra note 42, at 32-33.

162 POSNER, supra note 42, at 34 ("If every valuable . . . resource were owned by somcone (the criterion of universality), ownership connoted the unqualified power to exclude everybody else from using the resource (exclusivity) as well as to use it oneself, and ownership rights were freely transferable, or as lawyers say alienable (transferability), value would be maximized.").

The neoclassical approach to private property meshes well with a Lockean natural rights-based approach to private property, and both theories are inclined to favor broad private property rights. See sulpra note 96 (discussing Locke's theory of property and describing the debate as to whether a natural rights-based theory of intellectual property or neoclassical economics is most responsible for the increasing propertization of information). 
rights are exclusive. ${ }^{163}$ In addition, in order to assure that the property winds up in the hands of the person who values it most highly, neoclassicists favor property rights that are freely transferable. ${ }^{164}$ Neoclassical economics, therefore, proposes property rights that are universal, exclusive, and transferable. ${ }^{165}$

The different and sometimes competing strains of economic analysis are especially evident in the context of intellectual property analysis. ${ }^{165}$ In particular, it is important to distinguish the neoclassical economic approach to intellectual property from the economic incentive approach to intellectual property. While both schools of thought propose the assignment of private property rights as a resolution to the potential inefficiency of common ownership, incentivists view copyright as a limited monopoly, with some of the same attendant problems, and emphasize the need to balance the incentivizing benefits of copyright protection against copyright's detrimental impact on the dissemination and use of original works.

163 BLACKSTONE, supra note 24, at 2 (defining property as "that sole and despotic dominion which one man claims and exercises over the extemal things of the world, in total exclusion of the right of any other individual in the universe."); POSNER, supra note 42 , at 32.

164 POSNER, supra note 42, at 32-33; Hardin, supra note 49, at 6 ("The tragedy of the commons as a food basket is averted by private property.").

165 Property is often defined as a "bundle of rights." COOTER \& ULEN, supra note 42, at 91; Demsetz, supra note 50, at 347 . In Western free-market legal regimes, this bundle typieally includes (subject to some limitations) the rights of possession, use, transformation, transferability, and exclusion. COOTER \& ULEN, supra note 42, at 91; POSNER, supra note 42, at 32-33; see also. A.M. Honore, Omership, in OXFORD ESSAYS IN JURISPRUDENCE 107, 113-26 (A.G. Guest cd., 1961) (listing 11 common attributes of private property). Although all of the rights appurtenant to private property need not reside in the same individual, neoclassicists view such a division of property rights as ineficient. POSAER, supra note 42, at 66. For example, due either to custom or legal mechanisms, several persons may possess the right to exclude others from property, resulting in a potential anticommons. Michael A. Heller, The Tragedy of the Anticommons: Property in the Transition from Sfarx 10 Markets, 111 HARv. L. REV. 621, 675 n.246 (1998) (defining an anticommons as "a property regime in which multiple owners hold effective rights of exclusion in a scarce resource"). United States law, however, ploces serious restrictions on the rights of owners overly to decompose property. Id. at 664 ("[T]he owner may break up the bundle of rights, subject to the restriction that he or she may not 'decompose' the bundle in ways that overly impair the object's marketability.").

166 Cohen, supra note 96, at 466-67 (arguing that the "critiques of the neoclassieal paradigm supplied by institutional welfare, theoretic, and political cconomists have identified several factors that should inform efforts to determine the optimal system of rights in digital vorks"); Netanel, stupra note 14, at 308-11 (distinguishing the neoclassical economic justification for copyright protection from the economic incentive rationale for copyright).

167 Netanel, supra note 14, at 308-09. Just as the neoclassical economic approach to property meshed well with a Lockean natural-rights based theory of property, the economic incentive approach meshes well with a consequentialist or utilitarian philosophy of propeny rights. Utilitarianism posits that the state should adopt policies that enhance the welfare or utility of the members of the community. See JEREMY BENTHAM, AN INTRODUCTION TO THE PRINCIPLES OF MIORALS AND LEGISLATION 50 (Hafner Publ'g Co. 1948) (1789) (arguing that "natural rights is simple nonsense" and advocating a utilitarian approach). Utilitarians thus focus on intellectual property's role as providing incentives for the production of more information as a means to enhance public velfare, but recognize the comesponding costs in terms of decreased public access to goods that might othervise be more widely available. 
Neoclassicists, by contrast, view copyright not only as a spur to information production, but also as a means to facilitate market transactions that transfer creative works to their highest valued uses. ${ }^{168}$ Accordingly, neoclassicists regard intellectual property rights as beneficial, not only because they provide incentives for production, but also because they facilitate efficient resource allocation. ${ }^{169}$ Consequently, neoclassicists see little need for the legal balancing act favored by incentivists and, instead, favor strong property rights in information creators, leaving the subsequent allocation of those rights to the determination of market forces. ${ }^{170}$ It has been cogently argued that the expansion of intellectual property in this country is due primarily to the ascendance of neoclassical economics, and to Chicago School law and economics, over other schools of economic thought, such as the economic incentive theory. ${ }^{171}$

This recognition is extraordinarily important because it is information's role in maintaining market efficiency that necessitates the delicate balancing act required of information regulation in the insider trading context. In other words, in more traditional areas of intellectual property law, such as patent law and copyright law, the neoclassical proposal to grant broad property rights in information producers and allow the marketplace to resolve allocational issues has been criticized by some intellectual property commentators as failing to give sufficient weight to the extraordinarily important role that public access to information plays in promoting free and knowledgeable political debate and economic, scientific, social, and artistic progress. ${ }^{172}$ A similar criticism can be leveled at informational-propertarian proposals in the insider trading context. Were it not for the important role that public access to information plays in enhancing allocative efficiency, neoclassical proposals that favor broad grants of informational property rights without regard to the impact of such grants on information distribution would carry much more philosophical power. ${ }^{173}$

1. Challenges to the Neoclassical View of Property. While an analysis of the voluminous scholarly work on the benefits of private ownership as opposed to communal ownership is beyond the scope of this Article, it is

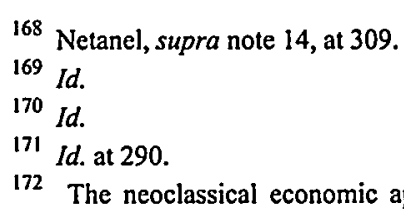
overly "narrow" and "simplistic" assumptions. Cohen, supra note 96, at 515-19.

173 This is not to suggest that informational efficiency is a sufficient condition for allocative cficiency. Other conditions such as, for example, low transaction costs, must also be present for allocative efficiency to hold. See Lynn A. Stout, The Unimportance of Being Efficient: an Economic Analysis of Stock Market Pricing and Securities Regulation, 87 MiCH. L. REv. 613, 617-18 (1988) (arguing that informational efficiency may not lead to allocational efficiency and is, therefore, unimportant as a policy objective). 
worth noting that the assertion that private ownership will result in the most efficient use of resources has not gone unchallenged. Most famously, of course, Karl Marx and Freidrich Engels advocated a system of collective ownership and derided private property as causing a wide variety of evils, including exacerbating wealth disparities and individual alienation. ${ }^{174}$ While experience has shown the difficulty of implementing this ideal into practice, the dream of collective living has had such a profound appeal that numerous societies have been founded on it, some with great success. ${ }^{175}$ More recently, many American academicians have made cogent arguments in favor of some forms of public ownership. ${ }^{176}$

2. The Second Aporia: The Efficiency Paradox. Even if neoclassical economic scholars are correct in their assertion that most resources are optimally produced and used in a system of private ownership, it is not clear that the same is true with regard to the use and production of information. As previously discussed, information allows marketplace actors to rationally choose among available resources. Information, therefore, is valuable and shares some similarities with other commonly bought and sold commodities. Unlike other valuable commodities, however, information is also central to efficiently functioning markets. In fact, so central is information to the ability of individuals to interact intelligently with one another that the presence of "perfect information" is one of the core assumptions of much economic theory. ${ }^{177}$

As noted by economists and legal scholars, however, these two competing roles played by information - a necessary precondition to efficient markets and a scarce commodity within the market whose production must be

174 See generally KARL MARX \& FrEIDRICH ENGELS, THE COMMUUNIST MANIFESTO (1848).

175 Ellickson, Property, supra note 51, at 1318 (discussing collectivization altempts in Israel, Russia, China, Ethiopia, and Kampuchea, and by more discrete groups, such as Protestant sectarians and hippie communes). Professor Ellickson demonstrates that common ownership can sustain some degree of success when voluntarily implemented by close-knit groups that develop strong internal controls, but that common ownership is destined to fail when imposed on unwilling groups by political leaders. Id. at 1320-21, 1399-1400.

176 For example, Professor Carol Rose has argued that some resourees, such as roads, waterways and beaches, may be most efficiently owned as common property. Sce Rose, supra note 54, at 718-23. In addition, Professors Duncan Kennedy and Frank Michelman have argued that private ownership does not necessarily lead to increased production or optimal efliciency. Kennedy \& Michelman, stpra note 67, at 717-20 (arguing that production of resources may be maximized in a "state of nature" us opposed to through a system of private ownership). Finally, Professor Robert C. Ellickson has argued that members of small, closely-knit groups tend to create cost-minimizing land regimes that incoporate a mix of private, group, and open-access spaces. Ellickson, Property, supra note 51, at 1397-98. Professor Ellickson further argues that some resources, for scale-economy or risk sharing reasons, may be more efficiently owned in common form. Id. at 1398.

177 GeORGE J. STIGLER, THE THEORY OF PRICE 82 (4th ed. 1987) ("A perfect market is one charaterized by perfect knowledge on the part of the traders."); Boyle, supra note 7, at 1443 (anguing that "the concept of 'perfect' information-meaning free, complete, instantaneous, and universally available[is] one of the defining features of the perfect market"). 
encouraged-are difficult to reconcile, leading to the second informational aporia. If markets are to be perfectly efficient, then information must be perfectly and costlessly available. ${ }^{178}$ If information is "costless," however, then there is no profit potential for the producer of information. ${ }^{179}$ Granting property rights to the producers of information may enable them to capture the benefits of production and encourage the creation of information. Granting property rights in information, however, introduces a transaction cost into the marketplace, impeding the free flow of information. ${ }^{180}$ As stated by Professors Grossman and Stiglitz: "There is a fundamental conflict between the efficiency with which markets spread information and the incentives to acquire information .... Because information is costly, prices cannot perfectly reflect the information which is available, since if it did, those who spent resources to obtain it would receive no compensation." 181

This tension between information as a precondition to fully informed efficient markets and information as a valuable commodity within the market is illustrated by the case of Board of Trade of the City of Chicago $v$. Dow Jones \& Co. ${ }^{182}$ In Dow Jones, the Chicago Board of Trade attempted to create and market a commodity futures contract based on the Dow Jones

178 Gilson \& Kraakman, supra note 6, at 552; Sanford J. Grossman \& Joseph E. Stiglitz, On the $/ \mathrm{m}$ possibility of Informationally Efficient Markets, 70 AM. ECON. REV. 393, 405 (1980). Professors Gilson and Kraakman, in their path breaking work on market efficiency, rephrased the debate as an attempt to explain why and how markets behave as if information is immediately and costlessly available, even when it is not. Gilson \& Kraakman, supra note 6, at 552.

179 Easterbrook, supra note 13, at 313 ("A rule allowing information to be used fully, once in cxistence, may well maximize the wealth of both the users and society. Yet the same rule would reduce the ability of those who create information to appropriate the benefits of their efforts, pcople would create less information."); Gilson \& Kraakman, supra note 6, at 571.

${ }^{180}$ Cf. Gilson \& Kraakman, supra note 6, at 593 (demonstrating that with lower information costs, information will be more widely distributed and will be more efficiently reflected in market price).

$18 \mathrm{t}$ Grossman \& Stiglitz, supra note 178, at 405. Kenneth Arrow demonstrated this tension between social welfare and private incentives by arguing that, while social welfare is enhanced by making information available free of charge, this results in a lack of incentives for private information production. Arrow, supra note 32, at 616-17. While a grant of private property rights in information producers would incentivize production, "precisely to the extent that it is successful, there is an underutilization of information." Id.

Professors Grossman and Stiglitz resolved the "efficiency paradox" by proposing the existence of an "equilibrium degree of disequilibrium." Grossman \& Stiglitz, supra note 178, at 393. They argued that "noise" prevented capital markets from ever reaching full efficiency, resulting in profit potential for informed traders and an incentive for information acquisition. Id. Professors Gilson and Kraakman expanded on this theory by recognizing that, due to temporal advantage, there is sufficient profit incentive to encourage the initial acquisition of new information. Gilson \& Kraakman, supra note 6, at 625. The paradox, therefore, was not how markets initially became efficient, but how they remained so. Id. They demonstrated that the costs of maintaining the equilibrium were virtually zero (because it was not Dependent on new information discoveries, but rather on the continuing exploitation of prior discoveries) and that these costs in any event would probably be incurred in connection with other trading strategies. Id. at 624-25.

182456 N.E.2d 84 (III. 1983). See Boyle, supra note 7, at 1450. Professor Paul G. Mahoney has examined similar issues in connection with the prices and other information generated by stock exchanges. Mahoney, supra note 13, at 1483-88. 
Industrial Average. ${ }^{183}$ The index futures prices at issue in the case present a classic collective good problem: like most other creative works, the prices take significant amounts of time, labor, and input to create, but once the information has been revealed it is available to others at nearly zero cost. ${ }^{184}$ While recognizing the tension between information as property and information as a precondition to efficient markets, ${ }^{185}$ the court nonetheless reasoned that if others could free ride on Dow Jones's efforts and use the prices at will, Dow would have a reduced incentive to create the prices and could withdraw from production, to the marketplace's detriment. ${ }^{86}$ As we have seen, one way to avoid this problem - and the method adopted by the court-is the creation of property rights in the information in question. ${ }^{187}$ Granting one marketplace actor this type of limited monopoly, however, imposes transaction costs on the distribution of an extraordinarily important piece of information relating to value-price ${ }^{188}$-leading to a potentially less efficient market.

This concern was explicitly addressed by Justice Simon in his dissenting opinion:

[W] e must balance Dow Jones' interest in preventing the use of its average by the Board of Trade against society's interest in the widest use and dissemination of intellectual property. Obviously, both interests are important and require fair consideration in the balancing process. Unless the creators of intellectual property allow it to be appropriated by people who have developed novel and productive uses for it, the pace of innovation will slow....

The majority errs, in part, because it has failed to place enough emphasis on the unfettered access to ideas in the public domain, a privilege which is essential to our free market ... economy. ${ }^{189}$

183 Dow Jones, 456 N.E.2d at 85.

184 Boyle, supra note 7, at 1449.

185 Dow Jones, 456 N.E.2d at 89 ("Competing with the policy that protection should be afforded one who expends labor and money to develop products is the concept that freedom to imitate and duplieate is vital to our free market economy.").

${ }^{186} \mathrm{Id}$. at 89-90.

187 Id. at 91; Boyle, supra note 7, at 1449-50.

188 Gilson \& Kraakman, supra note 6, at 572-79; David E. Van Zandt, The Market as a Property Institution: Rules for the Trading of Financial Assets, 32 B.C. L. REV. 967, 981 (1991) ("In a market in which there are frequent trades of large numbers of identical assets, the previous or the currently quoted price is often the most significant information to which a trader has access. Truders can safely and cheaply form their expectations of the true value of the asset by examining the price.").

${ }^{189}$ Dow Jones, 456 N.E.2d at 91. Justice Simon also argued that the expansion of intellectual property rights should be left to Congress or to state legislatures, not to the courts. Id. 


\section{B. Multiple Uses for Information}

Even assuming that endowing information producers with private property rights does not unduly hamper information dissemination, it is not at all obvious that issuers need any extra incentive to produce information about themselves. ${ }^{190}$ Economists have noted that the possibility of multiple profitable uses for the same information may provide sufficient incentives for information production, obviating the need for an endowment of property rights in information creators.

For example, Professor Jack Hirshleifer argued that the ability of information producers to speculate on price revaluations that might result from their inventions or discoveries could operate as sufficient compensation and incentive to information creation. ${ }^{191}$ As such, the grant of property rights to information producers, through a patent or copyright, for example, would result in overcompensation to information producers and operate as an incentive to socially wasteful overproduction of information. ${ }^{192}$

Professor Hirshleifer used the example of Eli Whitney's cotton gin to illustrate this point. ${ }^{193}$ Whitney spent much time and money attempting to protect his patent in the cotton gin, efforts that were largely unsuccessful. ${ }^{194}$ Hirshleifer conceded that Whitney and other would-be inventors could have been discouraged by these results from pursuing subsequent inventions. On the other hand, if Whitney had been successful in his efforts to limit use of the cotton gin, cotton production and consumption would not have expanded as it did. ${ }^{195}$ In other words, the reduction in possible future innovations may have been outweighed by the benefits of permitting the widest exploitation of the current technology.

This is particularly true if it is recognized that Whitney had numerous other means at his disposal to profit from his cotton gin invention. For example, rather than merely profiting from payments made by others in exchange for use of the technology as under the patent system, Whitney could have allowed anyone to use his invention free of charge and profited instead from speculation on the impact that the cotton gin would have on the economy, such as the price of cotton, the value of slaves, and the profit potential of cotton producing or shipping firms. ${ }^{196}$ This might have enabled both the socially optimal use and dissemination of the new innovation and provided sufficient incentives to encourage future invention. ${ }^{197}$ Other commentators have also recognized that this possibility of multiple profitable uses for the

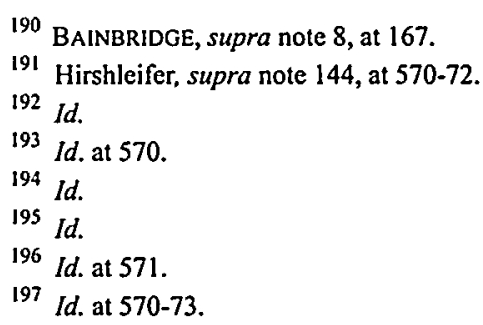


same information may provide sufficient incentives for information production, obviating or reducing the need for private property rights in information. ${ }^{198}$

Similarly, Justice (then Professor) Stephen Breyer questioned the necessity of copyright protection for most books, arguing that because the original author can profit from sales while subsequent producers take the time to copy the original work, only a modest fall in revenues could be predicted in the absence of copyright protection, which he believed would be offset by the public's greater access to books. ${ }^{199}$ Professor Breyer also noted that publishers had other means at their disposal to sustain revenues in the absence of copyright protection, including pre-publication contracts with buyers, negotiation with organized groups of buyers, and government subsidization of some works. ${ }^{200}$

Similar arguments apply to issuers and material inside information. Issuers create valuable information about themselves to operate a successful business enterprise, not to generate trading profits. Consequently, issuers are likely to engage in the same level of information production regardless of whether they are entitled to a property right in the information they create. Nothing is gained on the upside, therefore, by granting issuers, as information creators, a private property right in the information they produce. Much, however, is lost on the downside in terms of reduced informational access and dissemination. In other words, although granting issuers a private property right in information they create is unlikely to increase information production, it is likely to substantially decrease the public's access to information, resulting in reduced informational efficiency. ${ }^{201}$

198 See, e.g., Demsetz, supra note 29, at 306 (illustrating that if consumption of a publie good can be tied into consumption of a private good, then efficient production of the public good may be possible); Gilson \& Kraakman, supra note 6, at 624-25 (arguing that traders may unavoidably incur the costs of acquiring information about past stock prices in connection with other trading strategies); Kitch, stupra note 6, at 717-19 (discussing the possibility of multiple uses of information and its role in insentivizing information production); Landes \& Posner, supra note 58, at 331 ("Many authors derive substantial benefits from publication that are over and beyond any royalties."). Professors Landes and Posner, however, raise a variety of persuasive arguments negating the hypothesis that the possibility of altemase sourees of profit obviates the need for patent and copyright protection. Id. at 331-32.

199 Breyer, supra note 13, at 309; see also Landes \& Posner, supra note 58, at 330 ("Copying takes time, so there will be an interval during which the original publisher will not face competition.").

Many other commentators have noted the fact that timing advantages weaken the argument for intellectual property protection, although they differ in the extent to which they believe first mover advantages warrant eliminating or reducing intellectual property protection. For example, Professor Paul G. Mahoney has noted the importance of timing advantages in the context of stock exchanges. Mahoney. supra note 13, at 1488 ("The creators of a market face free rider problems, but counterbalansing thess are first mover advantages, particularly in securities markets. Once an exchange begins to attrast listings and investors, it can offer superior liquidity compared to the unonganized markets with which tt competes, which will attract more companies and investors and strengthen its advantage.").

200 Breyer, supra note 13, at 302.

201 See Zohar Goshen \& Gideon Parchomonsky, On Insider Trading, Markets, and "Negative" Property Rights in Information (2000) (unpublished manuscript, on file with the authos) (demonstrating 
Finally, the arguments made by Justice Breyer regarding the protections available to authors and publishers outside of the copyright context, such as private contracts, hold equally true with regard to the valuable inside information produced by issuers. Issuers are likely to have contractual relationships with most potential misappropriators and have the power to bind third parties to refrain from trading on information learned in the context of the contractual relationship.

\section{The Historical American Approach to Informational Property}

Finally, the American legal system's traditional reluctance to recognize property rights in information should, at the very least, cause a more careful consideration of the assertion that issuers are deserving of an exclusive property right in information about themselves. The historic American approach to informational property was best summarized by former Justice Brandeis: "The general rule of law is, that the noblest of human productions-knowledge, truths ascertained, conceptions, and ideas-become, after voluntary communication to others, free as the air to common use."202 Although some areas of intellectual property law recognize that the need to incentivize production may at times require limits on the use of information, it has for the most part avoided characterizing raw information as property.

For example, while trade secret law allows one to sue another who has improperly used secret information obtained in a confidential relationship, it has generally avoided characterizing the information itself as property. ${ }^{203}$ Similarly, copyright law attempts to protect expressions but not ideas. The reasons for these distinctions stem not so much from an inability to create property rights in information as from Enlightenment era views that the free dissemination of information unencumbered by such rights would lead to greater wealth, knowledge, and public debate, and to scientific, economic, and technological advancement.

In fact, intellectual property rights are a relatively recent development that most likely would have struck observers from previous centuries as strange. ${ }^{204}$ As stated by one eighteenth-century commentator:

I can read the contents of a book, learn, abridge, expand, teach, and translate it, write about it, laugh over it, find fault with it, deride it, use it poorly or wellin short, do with it whatever I will. But the one thing I should be prohibited

through an economic analysis that because insiders are isolated from competition, permission to trade on their informational advantages would cause them to prevent disclosure of valuable information to the marketplace, thus preserving their market power over inside information).

202 Int'l News Serv. v. Assoc. Press, 248 U.S. 215, 250 (1918) (Brandeis, J., dissenting).

203 Samuelson, supra note 39 , at 365 . While some trade secrets cases do refer to the information in question as property, the more accepted view appears to be that trade secrets are not the property of the entrustor of in formation. Id. at 374.

204 Aoki, supra note 18, at 26; Boyle, supra note 7, at 1463. 
from doing is copying or reprinting it? ... No, no, it is too obvious that the concept of intellectual property is useless. My property must be exclusively mine; I must be able to dispose of it and retrieve it unconditionally. Let someone explain to me how that is possible in the present case. Just let someone try taking back the ideas he has originated once they have been communicated so that they are, as before, nowhere to be found. All the money in the world could not make that possible. ${ }^{205}$

The rationale underlying the traditional American notion that information cannot be owned is ably illustrated by International News Service $\boldsymbol{\nu}$. Associated Press ("INS"), ${ }^{206}$ a "controversial and little followed" case that deviates sharply from the traditional American approach to intellectual property. ${ }^{207}$ In INS, International News Service (INS) had been prevented by foreign governments from cabling news of the war in Europe back to the United States. INS employees instead gathered war information by reading it in Associated Press (AP) newspapers or reading dispatches posted at AP offices and then reprinting the information contained therein. The case is similar to most insider trading cases in that the employees learned of the information primarily through legal means. ${ }^{208}$ Justice Pitney, writing for the majority, found that AP had a "quasi-property" right in the information in question. In other words, although after publication news became common property as regards the general public, AP had a property right in the information as against INS. ${ }^{209}$ In reaching its ruling, the majority used a classic law and economics argument: news gathering is expensive. If AP could not exclude others from using the information it uncovered and thus capture the profits, then it would have no incentive to create the information and would go out of business. The public would suffer accordingly. ${ }^{210}$

In dissenting opinions, both Justice Holmes and Justice Brandeis disagreed with the Court's property rights in information approach. They argued that not only was such a sweeping approach unnecessary, but also suggested that the Court had failed to consider the significant implications of such a departure from the traditional treatment of information in the American legal system. 211

205 Christian S. Krause, ber den Buchernachdruck, I DEUTSCHES MUSEUM $415-17$ (1783), quoted in Woodmansee, supra note 95, at 443-44.

206248 U.S. 215 (1918).

207 Kitch, supra note 6, at 699.

208 Apparently some information was obtained from AP employees by unlawful means, primarily through bribes. These instances were not before the Supreme Court, however, as INS did not appeal that portion of the trial court decision. Int'l News Serv., 248 U.S. at 231-32.

209 Id. at 236. This "quasi-property" right was limited in duration, however. The coun ruled that AP's property interest in its published news items lasted "until its commercial value as news to the complainant and all of its members has passed away." Id. at 245.

210 Id. at $240-41$.

211 Id. at 246-48 (Holmes, J., dissenting); id. at 248-67 (Brandeis, J., dissenting). 
Justice Holmes, in an opinion that foreshadows some of the arguments made by today's postmodernist scholars, argued that property rights did not stem automatically from natural law because an item had value. ${ }^{212}$ Rather, property rights were nothing more than creations of law stemming from the belief that the right to exclude others is necessary to protect the possessor from unwanted interference. ${ }^{213}$ In this case, however, such a grant of property rights was unnecessary because unfair trade law provided adequate protection for AP. ${ }^{214}$

Justice Holmes's thoughts still ring true today. Many intellectual property scholars today are critical of what they perceive as a modern trend toward a greater commodification of information. They express concern that the public domain is increasingly viewed as an intellectual backwater where only ideas undeserving of protection rest, rather than as a default position where information rests until a compelling public policy justifies removing it from the public domain and into private ownership. ${ }^{215}$ This perceived trend toward greater information commodification, arguably visible in many recent cases, causes uneasiness among some commentators who believe that a diminished public domain of ideas carries significant negative consequences for social, cultural, technological, economic and political development. ${ }^{216}$ This trend is also arguably visible in the rise of justifications for the insider trading prohibition based on the issuer's property right in valuable inside information, with the same potentially negative impact on the public domain of information and, correspondingly, on market efficiency.

The other INS dissenter, Justice Brandeis, also held potential insights for the insider trading debate. In a famous opinion, he argued against the creation of a property right in the AP news items. Justice Brandeis charged

\footnotetext{
212

See, e.g., Aoki, supra note 14, at 1318 ("Is something valuable because it's legally protected, or is it legally protected because it's valuable?").

213 Int'l News Serv., 248 U.S. at 246 (Holmes, J., dissenting).

214 Id. Samuelson, supra note 39 , at 392 . This same argument could be made in the insider trading context. There is nothing to prevent issuers from requiring confidentiality agreements from those with whom they transact business. Such contracts could prohibit third parties from trading on information acquired in the course of doing business with the issuer, obviating the need for a grant of property rights in the issuer. While it has been correctly noted that enforcement of such contracts would be more difficult if insider trading law were privatized in this manner, I believe that the benefits of deregulating insider trading by corporate outsiders outweighs the costs. Bainbridge, supra note 5, at 1625 (arguing that Professor Larry Ribstein's arguments in favor of private enforcement are unpersuasive); see also infra Part VI (proposing a federal regime that permits insider trading by corporate outsiders).

215 Jessica Litman, The Public Domain, 39 EMORY L.J. 965, 968 (1990) ("The public domain should be understood not as the realm of material that is undeserving of protection, but as a device that permits the rest of the system to work by leaving the raw material of authorship available for authors to use.").

216 Aoki, supra note 14, at 1323-24; Breyer, supra note 13, at 283-84 (arguing against stronger copyright laws); Wendy J. Gordon, An Inquiry into the Merits of Copyright: The Challenges of Consistency, Consent, and Encouragement Theory, 41 STAN. L. REV. 1343, 1460-61 (1989); Litman, stupra note 215, at 965-67. The number of scholarly works reflecting concem over increased intellectual property rights and a decreasing public domain in American law are too numerous to cite here. A more thorough citation and survey is available in Aoki, supra note 18, at 8-10.
} 
that the majority did not consider the public's interest in vital informationnews about the war in Europe. He noted that half the nation read non-AP newspapers and argued that there was an important public interest in affording them a supply of accurate, timely news information. ${ }^{217}$

Justice Brandeis, noting the traditional reluctance of the American legal system to recognize property rights in information, argued that the normal rule was that information and ideas were not subject to property rights and that exceptions were granted-as in the copyright and patent clausesonly by the legislature and only when public policy seemed to demand it. ${ }^{218}$ $\mathrm{He}$ noted that the legislature was better able than the judiciary to weigh all the factors, engage in the necessary debate, and craft carefully limited remedies. ${ }^{219}$ Similar arguments have been made in the insider trading context by observers who believe that current insider trading law, and the misappropriation theory in particular, are a misguided judicial attempt to regulate informational asymmetries in the absence of legislative guidance. $^{220}$

\section{THE MIDDLE GROUND-NONEXCLUSIVE "PROPERTY RIGHTS" IN CORPORATE OUTSIDERS}

I have attempted so far in this Article to deconstruct the artificial distinctions between conceptions of information in the public and private spheres that motivate much of the insider trading debate. In so doing, I have argued that there is nothing inherently unfair about insider trading, and that there is no justification for informational-egalitarianism, given the many other forms of inequality, including inequalities in access to information, that are not only tolerated, but often considered the norm in the United States legal system.

Similarly, I have argued that no person has an inherent property right in the information that she creates. The imagined private sphere, which protects through property rights certain items from intrusion by others, is merely a state creation designed to further a specific economic purpose. In

217248 U.S. at 263-64 (Brandeis, J., dissenting).

218 Id. at 250 (Brandeis, J., dissenting).

219 One alternative, for example, that would encourage the dissemination of information yet still provide AP with profit would be a rule that protected AP's news against appropriation by competitors, but forced AP to disclose the information to others at a reasonable price and without discrimination. Id. at 266-67 (Brandeis, J., dissenting); see also Samuelson, supra note 39, at 366-67 (arguing that the recharacterization of information as property is a revolutionary event that, at the very least, should be undertaken after thorough thought and careful debate-not accidentally and in an ad hoe manner by judges intent on reaching what they perceive to be an equitable result).

220 See, eg., Painter et al., supra note 116, at 156. Professor Stephen Bainbridge, while acknowledging that the current insider trading regime was not authorized by Congress, has skilliully argued that the costs of changing course at this juncture are so great that insider trading regulation should be permitted to continue down its current "path dependent" course, with some doetrinal modifieations. Bainbridge, supra note 5, at 1589-91. 
the case of insider trading, however, it is doubtful that issuers require a property right in the information that they create in order to encourage production. Given the damage that such property rights may inflict on informational efficiency, we should be wary of unnecessarily endowing issuers with informational property rights.

Although it is unnecessary to incentivize the production of valuable inside information, the need to encourage the dissemination of such information to the marketplace has been the topic of extended discourse for many years. ${ }^{221}$ Clearly, a rule that would require issuers to disclose all material nonpublic information (an "always disclose rule") would most fully achieve both informational efficiency and informational equality. ${ }^{222}$ Accordingly, if increased corporate disclosure and fairness in access to information among securities market participants is the desired goal, then disclose or abstain theories of liability, including the classical, misappropriation, and equality of access theories, fall short of achieving that objective. ${ }^{223}$ Because a disclose or abstain rule permits the corporation and its insiders to withhold relevant information so long as they do not trade in the corporation's securities, a disclose or abstain rule encourages abstention rather than disclosure. ${ }^{224}$ This affords insiders an informational advantage over outsiders: so long as relevant information affecting stock prices remains undisclosed, outsiders trade blindly in a market that may not accurately reflect stock value. ${ }^{225}$ By contrast, insiders will know to refrain from trading until the market is well-informed. ${ }^{226}$

221 Compare, e.g., Frank Easterbrook \& Daniel Fischel, Mandatory Disclosure and the Protection of Investors, 70 VA. L. REV. 669, 682-84 (1984) (arguing that managers have sufficient market incentives to encourage corporate disclosure without mandatory disclosure regulations), with John C. Coffec, Jr., Market Failure and the Economic Case for a Mandatory Disclosure System, 70 VA. L. REV. 717, 722-23 (1984) (arguing that a mandatory disclosure system is needed), and Joel Seligman, The Historical Need for a Mandatory Corporate Disclosure System, 9 J. CoRP. L. 1 (1983) (presenting historical evidence of fraudulent disclosure and underdisclosure prior to the enactment of the Securities Acts).

222 Gilson \& Kraakman, supra note 6, at 632 n.218; Levmore, supra note 23, at 119-20.

223 The "disclose or abstain" rule was first articulated by the Commission in In re Cady. Roberts \& Co., 40 S.E.C. 907,912 (1961). The Commission held that a corporate insider in possession of material nonpublic information must either disclose that information or refrain from trading. Id. The rule was later expanded under the misappropriation theory to cover persons who acquired nonpublic information in breach of a fiduciary duty. United States v. O'Hagan, 521 U.S. 642, 652 (1997).

224 Bainbridge, supra note 5, at 22-23 (arguing that current insider trading law's disclose or abstain rule "collapses into a rule of abstention" because agency law prevents the firm's agents from disclosing corporate information when such disclosure would harm the corporate principal); Cox \& Fogarty, supra note 117, at 353 ("The "disclose or abstain" rule for those entrusted with confidential information usually is observed by abstention."); Easterbrook, supra note 13, at 327 (noting that a disclose or abstain rule usually results in abstention, not disclosure, and consequently does not encourage the relcase of relevant information to the market); Levmore, supra note 23, at 123.

225 Levmore, supra note 23, at 123.

226 Id. at 123-28. The example used by Professor Levmore as illustration is S.E.C. v. Texas Gulf Sulphur, 401 F.2d 833 (2d Cir. 1968). In Texas Gulf Sulphur, the corporation had information indicating that a valuable ore deposit made the company's shares more valuable than the market realized. Insiders 
There are, of course, numerous reasons to reject an always disclose rule despite its informational efficiency and equality advantages, and the Supreme Court has explicitly rejected the idea that corporations owe a general duty to disclose relevant information to the marketplace. ${ }^{227}$ In fact, nearly every commentator that has studied the issue has rejected an always disclose rule as impractical. ${ }^{228}$ In particular, it has been noted that while the always disclose rule would result in greater informational efficiency, it could also result in allocative losses to shareholders by forcing the disclosure of information that could benefit competitors or jeopardize corporate plans. ${ }^{229}$

Given these problems with the mandated disclosure of material information, a rule that encourages transmission of information to the marketplace without actual disclosure holds the promise of promoting both allocative and informational efficiency. In fact, many commentators who have advocated a rule permitting insider trading have defended their proposal on exactly these grounds. ${ }^{230}$

The earliest, and perhaps most controversial, of these commentators was Professor Henry G. Manne. ${ }^{231}$ Manne stunned the legal community in 1966 with the publication of an extended defense of insider trading. Manne proposed the following two general justifications for the repeal of insider trading laws: first, insider trading contributed to market efficiency by transmitting material nonpublic information to the marketplace and, second, permitting corporate insiders to profit from their access to material nonpub-

were aware of this, and therefore knew not to sell their shares into the underalued market. Outsiders, however, were unaware of these facts and, therefore, may have continued to sell their shares at less than fair value. Levmore, supra note 23, at 123. Professor Levmore recognized that outsiders as a group may not be harmed by the disclose or abstain rule because it is just as likely that some shareholders may have purchased undervalued shares as it is that some shareholders may have sold undervalued shares. Id. Nonetheless, he argued that the rule is ultimately unfair to outsiders because they are forced to trade "randomly" risking the misfortune of trading in an uninformed market, while insiders could abstain and avoid these risks. Id. at 123-24. While the disclose or abstain rule would not place the Texas Gulf Sulphur investors on an equal informational footing with insiders, therefore, an always disclose rule would. Id at 124-28.

227 Basic, Inc. v. Levinson, 485 U.S. 224, 239 n.17 (1988) (“Silence, absent a duty to diselose, is not misleading under Rule 10b-5."); Dirks v. SEC, 463 U.S. 646, 654-55 (1985) (same); Chiarella v. United States, 445 U.S. 222, 235 (1980) (holding that a duty to disclose does not arise from the mere possession of material nonpublic information).

228 Levmore, supra note 23, at 132.

229 For example, disclosure of an impending tender offer would jeopardize the suecess of the offer by attracting rival bidders or alerting the target to implement talicover defenses. Diselosure of new products or procedures would alert competitors and jeopardize first mover advantoges. Retuming to the Texas Gulf Sulphur example, a rule that forced Texas Gulf to disclose the secret ore deposits would have resulted in a more accurate price for Texas Gulf Sulphur stock, but also may have threatened the opportunity for the valuable land sale purchase, resulting in a huge loss for the Teras Gulf Sulphur shareholders. Levmore, supra note 23, at 135-36. Furthermore, an always disclose nule may reduce the insentives to produce valuable information, such as the ore deposits discovered-at great expense-by Texas Gulf Sulphur. raising further questions of allocative efficiency. Gilson \& Krazkman, supra note 6, al 632 n.218.

230 See sources cited infra notes 6,9.

231 See, e.g., MANNE, INSIDER TRADING, supra note 9; Manne, supra note 6. 
lic information would operate as an effective entrepreneurial compensation scheme. ${ }^{232}$

While both of these justifications have been criticized, Professor Manne deserves credit for recognizing the dual role that information plays as both a precondition to efficient markets and a valuable commodity within the market and for highlighting the fact that society's approach to insider trading necessarily entails a tradeoff between these competing objectives. His proposal contended that permitting insider trading struck the best compromise between these two divergent needs. That is, Manne argued that a law permitting insider trading would encourage the production and dissemination of valuable information by allowing information producers to reap the benefits of their labor while also contributing to accurate security prices, thus enhancing informational efficiency. ${ }^{233}$

Manne's arguments that insider trading profits could reward entrepreneurial effort are the most controversial element of his proposal, and with good reason. First, Professor Manne's justifications of the proposal are replete with author reasoning that romanticizes insider traders and obscures the negative consequences that can arise from their actions. ${ }^{234}$ Second, the contention that insider trading is an efficient compensation scheme has been disputed by nearly every commentator who has considered the issue. ${ }^{235}$ For example, scholars have argued that insider trading is an inefficient compensation scheme because it equally rewards the production of both good and bad information, is limited by the insider's access to capital to purchase shares or options, and is impossible to restrict to those who actually create the information. ${ }^{236}$

In addition, a system that rewards corporate insiders with trading profits creates many perverse incentives. For example, allowing insiders to profit from valuable inside information may encourage market manipulation, the delay of public disclosure of relevant information, and business decisions that impair shareholder wealth but create insider trading opportu-

232 MANNE, INSIDER TRADING, supra note 9, at 93-110, 131-45.

233 Id. at 80-90.

234 Manne refers to the entrepreneur as an innovator, an "upsetter of stable socicties" and a "creator of disruptive forces." MANNE, INSIDER TRADING, supra note 9, at 119. Such a person would not be content to earn a mere salary, he contends, but instead must be rewarded with a share of the corporation's profitability. Id. at 131-45. Bonuses and stock options are ineffective, however, because the entrepreneur is "limited to a specific reward no matter how great his innovation." Id. at 138. According to Manne, only insider trading profits can adequately attract entrepreneurs and encourage their necessary innovations: "a rule allowing insiders to trade freely may be fundamental to the survival of our corporate system. People pressing for the rule banning insider trading may inadvertently be tampering with onc of the wellsprings of American prosperity." Id. at 110.

235 See, e.g., Easterbrook, supra note 13, at 332; Gilson \& Kraakman, supra note 6, at 632-33 n.221; Levmore, supra note 23 , at 145 n.75.

236 See id. 
nities. $^{237}$ Furthermore, it is unlikely that market forces would act to constrain decisions to opt out of insider trading laws that are not in shareholders' best interests. Commentators have noted the tendency of the markets for corporate control and managerial labor to fail with respect to issues involving significant redistributions of wealth from shareholders to managers, as in the case of insider trading. ${ }^{238}$ For these reasons, unlike many other scholars who have attempted to privatize some portion of federal insider trading law, this Article does not advocate contractual solutions to the problem of insider trading by actual or constructive corporate insiders. ${ }^{239}$

Manne's views regarding the role of insider trading in promoting informational efficiency have met with more acceptance from both legal academics and economists, although there is some debate as to the speed and efficiency with which stock prices change in response to the information transmitted by insider trading. ${ }^{240}$ As discussed, there is no doubt that insider trading is not as effective a means of disseminating new information

237 See, e.g., Robert J. Haft, The Effect of Insider Trading Rules on the Internal Efficiency of the Large Corporation, 80 MICH. L. REV 1051, 1053-60 (1982) (anguing that insider trading may harm the corporation due to delayed transmission of information to superiors within the firm); id. at 1062-63 (arguing that the possibility of insider trading can injure the corporation by generating distrust and ill-will among management and thereby negatively affect corporate decision making); Easterbrook, supra note 13, at 331 (arguing that insider trading by corporate employees during the planning stages of a business combination can affect the target's share price, increasing the cost of the acquisition to the bidder and endangering completion of the transaction); Carlton \& Fischel, supra note 3, at 884 (same); Easterbrook, supra note 13, at 333 (arguing that the opportunity to trade legally on inside information may encourage the delay of relevant corporate information, resulting in less market efficiency); Levmore, supra note 23, at 149-50 (same); see also Bainbridge, supra note 4, at 49-55 (discussing each of these potential dangers and the arguments that have been levied against them).

238 Lucian A. Bebchuck, Federalism and the Corporation: The Desirable Limits on State Competition in Corporate Law, 105 HARV. L. Rev. 1435 (1992); see also Henry N. Butler, The Contraetual Theory of the Corporation, 11 GEO. MASON L. REV. 99 (1989) (anguing that market forces do not adequately constrain managers during "last-period" problems, when the benefits of a certain action substantially outweigh any penalties imposed by the managerial labor market); Emst Maug, Insider Trading Legislation and Corporate Governance (March 25, 1999) (unpublished manuseriph, on file with author) (finding that "[p]rivate contracting between companies and shareholders leads to optimal insider trading regulation only if initial shareholders can enter a binding commitment, othenvise large shareholders and managers recontract at the expense of small shareholders"). Similarly, evidence indicates that legal changes negatively impacting shareholder welfare are not accurntely reflected in share price. Elliot J. Weiss \& Lawrence J. White, Of Econometrics and Indeterminacy: A Study of Investors" Reactions to "Changes" in Corporate Law, 75 CAL. L. REv. 551 (1987).

${ }^{239}$ See, e.g., Macey \& Haddock, Coasian Model, supra note 9, at 1451 (advocating a contractarian approach to insider trading regulation).

240 Gilson \& Kraakman, supra note 6, at 630-32 (arguing that insider trading transmits relevant information to the marketplace slowly and ineficiently and, absent a rule requiring insiders to diselose their trades, is unlikely substantially to further market efficiency); Macey, supra note 107, at 275-76 (noting that "[e]conomists generally agree that insider trading will generally lead to more accurate stock prices"); Richard W. Painter, Insider Trading and the Stock Market Thirty Years Loter, 50 CASE W. RES. L. REV. 305, 308 (1999) (stating that "the insider trader makes market prices more aceurntely reflect all available information"). 
to the marketplace as is actual disclosure. ${ }^{241}$ The decoding of insider trading activity performed by savvy investors is a relatively slow and "noisy" process. ${ }^{242}$ Nonetheless, given that immediate disclosure of nonpublic corporate information is normally not required by federal securities law and in many cases could jeopardize legitimate business projects, insider trading by corporate outsiders with no control or influence over the issuer's information flow may be the next best alternative.

Accordingly, this Article advocates a privatization of outsider trading law, by arguing that regulators should leave issues regarding the permissibility of insider trading by corporate outsiders to state contract law, rather than to federal securities law. Furthermore, states should avoid the Supreme Court's error of leaving the determination of when a "relationship of trust and confidence" exists sufficient to impose liability under the misappropriation theory, by imposing liability for outsider trading only when an express (though not necessarily written) confidentiality agreement exists.

Under this proposed regime, federal securities law would permit insider trading by corporate outsiders, defined as those persons who are neither employees nor constructive insiders of the issuer and who did not receive their information in a tip from the issuer's employees or constructive insiders. ${ }^{243}$ Such a regulatory regime provides the hope of filling in the gaps left by the current disclose or abstain system, by encouraging the reflection of certain information in stock market price without disclosure of the actual inside information. Furthermore, this proposal leaves unchanged federal law regarding the trading and tipping activities of corporate insiders and constructive insiders - those parties who have assumed a fiduciary duty to the corporation and its shareholders and who often control the corporation's information flow to the outside world. Accordingly, this proposal avoids the perverse incentives and negative impacts on market efficiency attendant in a system that permits insider trading by such parties.

The reality is that many corporate outsiders who frequently come into contact with valuable inside information are in a contractual relationship with the issuer or its insiders and will be prevented by confidentiality agreements from trading on or disclosing the information acquired during

\footnotetext{
241 See supra notes $178-81$ and accompanying text.

242 The effectiveness of information transmission through insider trading could perhaps be increased through Commission filing requirements. For example, the Commission could require corporate outsid. ers to file their intention to trade on inside information (but not the information itself) thus reducing the costs associated with trade decoding. Gilson \& Krakman, supra note 6, at 630-32; Steven Huddart et al., Public Disclosure of Insider Trades, Trading Costs, and Price Discovery (June 26, 1998) (unpublished manuscript, on file with this author) (finding that mandatory disclosure accelerates price discovery). The problem posed by such a filing requirement is the means by which people would be induced to file. Voluntary disclosure absent some Commission enforcement mechanism is unlikely. However, granting the Commission enforcement power over such filings is unworkable because it reinserts regulators into the outsider trading regime.

243 See supra note 26 (explaining tippee liability).
} 
the course of that relationship. Accordingly, this proposal does not "legalize" outsider trading so much as transfer the burden of enforcing such agreements from the Commission, which is currently overburdened and whose enforcement of such agreements has been costly and ineffective, to private parties and state courts.

The Commission's monitoring expertise could also be employed to assist issuers with the enforcement of private contracts regarding the use of valuable corporate information. Because the Commission will continue to monitor and enforce federal prohibitions against trading by corporate insiders, and because Commission investigations of unusual stock price movements in advance of an important public announcement will reveal outsider as well as insider trading, the Commission could share information regarding outsider trading with the issuing corporation, thus easing the burdens faced by issuers in restricting the unauthorized use of corporate information. ${ }^{244}$

A regulatory system that privatized the law of outsider trading also provides enormous advantages over existing federal law in terms of clarity. Unlike the regulation of outsider trading under the misappropriation theory, which leaves the determination of when an outsider has traded in violation of a "duty of trust and confidence" to an almost case-by-case analysis, ${ }^{245}$ privatizing the law of outsider trading lends clarity to the regulatory scheme by permitting under federal law all outsider trading that does not involve an insider tip. Furthermore, outsider trading that does not involve an insider tip would give rise to civil liability under state contract law only if done in contravention of an express agreement.

Nonetheless, the clarity benefits of this proposed regime should not be overstated. Many insiders will no doubt attempt to evade the federal limitations on insider trading by trading through or tipping friends and family members and then arguing that these illegal trades and tips are actually misappropriations, which are governed by state contract law. Because there would be no express confidentiality agreement in such cases-otherwise the accomplice would presumably refuse to enter the scheme and risk personal liability-some instances of insider trading will go unpunished by either state or federal law.

Some of the more egregious instances could be prevented by allowing the Commission to bring enforcement actions when it believes that an insider has attempted to disguise her trades in this manner, but the burden of proof would be on the government to show that what appears to be outsider

244 See Ribstein, supra note 5, at 170 (arguing that misappropriation cases should be governed by state law, but that the Commission should share information regarding outsider trading with issuers and state regulators, similar to the information sharing activities of the FBI with state law enforement agencies).

245 See Painter et al., supra note 116, at 196 (criticizing the misappropriation theory adopted by the Supreme Court for lacking sufficient clarity). 
trading is, in fact, disguised insider trading. This means that some insider trading will continue to slip through the regulatory system unpunished. This author, however, is prepared to tolerate this cost as being outweighed by the reduced regulatory costs and increased informational efficiency that stem from such a legal system.

To illustrate how this proposed regime differs from current insider trading law, assume that a son enters his parent's home unannounced and overhears his father engaged in a telephone conversation in another room. ${ }^{246}$ In that conversation, the son hears his father, the CEO at a top entertainment industry firm, reveal that the company is about to be sold to a Japanese firm. After the father hangs up, he realizes that his son has overheard the conversation and implores his son not to trade on the information. The son later reveals the secret information to a number of friends and family members who, in turn, trade on the information.

Under current insider trading law, this case would be treated as one of misappropriation, followed by subsequent tipping. The son's liability as a tipper would thus turn on the following two issues: (1) whether the relationship between father and son was one of "trust and confidence" and (2) whether the son had received some personal benefit from the tip. ${ }^{247}$ Neither of these issues is entirely clear, and the nature of the relationship between father and son, in particular, would require the court to engage in extensive fact finding. . $^{48}$

Under the regulatory regime proposed in this Article, federal law would not regulate the son's activities because he is neither an employee nor a constructive insider of the issuer. Accordingly, any harm suffered by the information source-the father-would be left to state law remedies, or,

\footnotetext{
246 These facts are derived from the real case of Jonathan Sheinberg's alleged misappropriation of information from his father, Sid Sheinberg, regarding the sale of MCA to Matsushita, and Jonathan's subsequent tips to his wife's lover, his own lover (who told her mother, who told her husband) and his business manager. James B. Stewart, The Tipster, THE NEW YORKER, Jan. 17, 1994, at 54-71.

247 See id. (discussing the fact that both of these elements presented problems for the Commission's case). Under the Commission's new rule 10b5-2, a relationship of trust and confidence is decmed to exist whenever a person receives confidential information from certain enumerated family members, including spouses, parents, children, and siblings. The person receiving the information, however, has an affirmative defense if she can demonstrate that the particular facts and circumstances of that family relationship prevented a relationship of trust and confidence from developing. 17 C.F.R. $\$ 240.10 \mathrm{b5}-2$ (2000); see also Kimberly D. Krawiec \& Richard W. Painter, New Insider Trading Rule Attempts to Clarify SEC's Approach, CORP. COUNS. WKLY., Nov. 1, 2000, at 8 (discussing Rule 10b5-2 and concluding that "the Rule is fraught with ambiguity").

248 In fact, the difficulty in proving that Sid and Jonathan shared a relationship of trust and confidence was part of the incentive for the Commission to settle the Sheinberg case. The nature of Sid and Jonathan's relationship presented serious obstacles to the Commission's case, because Sid argued that he did not trust his son and because it was not obvious that Jonathan had ever agreed to his father's requests for secrecy. Stewart, supra note 246, at 69 . New Rule 10b5-2 does little to alter the problems involving the relationship between Sid and Jonathan Sheinberg, but shifts the burden of proof from the government to the defendant.
} 
more likely, to informal family mechanisms for punishing members who deviate from accepted forms of conduct.

Needless to say, absent significant expenditures of time and money by the Commission, this proposal shifts a large portion of the responsibility for monitoring outsider use of inside information to private parties, but that is exactly the intention of this proposal. ${ }^{249}$ Current outsider trading regulation is expensive, ineffective, and siphons limited resources away from federal projects that could perhaps make better use of such funding. ${ }^{250}$ To make matters worse, the injuries caused by outsider trading and the benefits provided by its prohibition are, at best, amorphous, and it is unclear whether any benefits of current federal outsider trading regulation, in terms of maintaining investor confidence in the markets and increasing market liquidity, outweigh the costs of enforcement and decreased informational efficiency. ${ }^{251}$ Accordingly, until regulators further analyze the costs and benefits of outsider trading regulation, this Article proposes that the regulation of such trading be left to private contract.

\section{CONCLUSION}

The goal of this Article has been to shed light on the reasons for our longstanding inability to answer the seemingly simple question of when one party must disclose information unknown to her trading partner. Until the reasons for this inability are identified, the question cannot be answered. The fairness concerns expressed by informational-egalitarians are deceptively beguiling. Few commentators, after all, would actively argue against a more equitable society. That this egalitarian goal should emerge in the context of information jurisprudence is also understandable, given the extraordinarily vital role that information plays in our society as a prerequisite to knowledgeable choice. It should be remembered that the Constitutional framers and other founders of the United States believed keenly in the widespread dissemination of thoughts, ideas, information, and expression and felt strongly that informational asymmetries between citizens would prevent full and knowledgeable debate and the realization of the goals of democracy.

249 Professor Stephen Bainbridge has cogently argued against the privatization of insider trading law on precisely these grounds. Bainbridge, supra note 5, at 1625 (anguing that Professor Lary Ribstein's anguments in favor of private enforcement are unpersuasive). Nonetheless, this author remains convineed that the costs of current federal outsider trading regulation outwcigh any potential benefits.

250 Empirical evidence indicates that, although U.S. regulators have experienced great success in deterring illegal insider trading by classical and constructive insiders, U.S. regulatory efforts have bren largely ineffective in deterring illegal outsider trading. Arshadi, supra note 111 , at 70 (finding that insider trading regulation in the United States has been reasonably effective at deterring tredes by "registered and temporary insiders," but has failed to deter illegal insider trading by corporate outsiders).

251 See supra Part IV (discussing at length the alleged harms to investors and market integrity due to insider trading and concluding that, although sound policy reasons exist for the federal prohibition against insider trading by the issuer's employees and constructive insiders, the costs of the federal prohibition against outsider trading outweigh the minimal benefits provided by the prohibition). 
Because the distributional effects of informational-egalitarianism are often concealed by false public/private distinctions, however, it represents the easy way out. In other words, informational-egalitarianism, and its subconscious misperception of information as infinite or limitless, presents the false hope that some members of society can be benefited while the others give up nothing in return. This Article demonstrates, however, that public mandates of informational equality, as through the legal prohibition of insider trading, do not significantly reduce information asymmetries. Because inequalities in access to information replicate inequalities in endowments of wealth, education, and access to human capital, it is the private sphere, not the public, that dictates-and limits-the possibilities for information acquisition.

Informational-propertarians are understandably puzzled by this unusual pocket of egalitarianism in the securities markets - the heart of a competitive market system that normally rewards its participants precisely because they do possess some advantage in wealth, education, or knowledge. In searching for some rational justification for insider trading regulation, they converge on a theory that, admittedly, holds substantial appeal: a propertyrights based approach that affords the hope of both resolving the extraordinary doctrinal tensions caused by the Supreme Court's tortured interpretation of Rule 10b-5, and of replacing amorphous fairness concerns with more "scientific" economic analysis. ${ }^{252}$

Yet, the recognition that insider trading regulation is essentially a matter of allocating property rights in valuable information does not end the analysis. All information regulation-not merely insider trading lawsmust perform a delicate balancing act that creates incentives to produce information without erecting undue barriers to use and dissemination of information. A combination of neoclassical economics and Lockean naturalrights based theories seems to have led to a modern assumption that property rights inevitably arise in an item merely because it has value. In fact, property rights are creatures of law arising from the belief that compelling public policies demand removing some items from the public domain and placing them into the hands of private ownership.

As this Article has demonstrated, because issuers require no inducement to produce valuable inside information, no public policy demands the creation of intellectual property rights in issuers. In fact, due to the decreased public access to information likely to result from such a regime, public policy weighs against endowing issuers with such rights. On the other hand, compelling public policies favor incentivizing the dissemination of information to the marketplace. Accordingly, a nonexclusive property

\footnotetext{
252 Manne, supra note 6, at 3 (stating that economics "is perhaps the most scientific of the social sciences. Here the word scientific must connote objectivity and moral detachment, as well as systematic verification of results. ... The question for an economist is rarely one of the mutual fairness of a transaction between individual parties.").
} 
right in corporate outsiders who possess inside information may strike the most appropriate balance between incentives and access-a difficult balancing act, but one that is performed with some measure of success in connection with other types of intellectual property. 